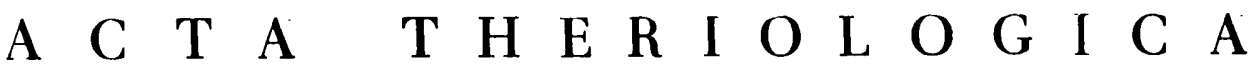

VOL. XII. 29: 407-444.

BIAŁOWIEŻA

30.XII.1967

\author{
Zbigniew KR A S I ŃSKI \& Jan R A C Z Y N S K I
}

\section{The Reproduction Biology of European Bison Living in Heserves and in Freedom}

\author{
Bisoniana XXV
}

[With 7 Tables \& 5 Figs.]

The investigations were based on documentation from Polish breeding reserves for the period 1954-1965 and on observations of a freeliving bison herd in the Białowieża Primaeval Forest for the period 1958-1966. The rutting period reaches a peak in the month of August, September and October. while copulation was observed over the greater part of the year with the exception of the anoestrus period: April June. Calving takes place from April to December, the greatest numbers of calves being born during the period May-July $(70 \%$ in reserves and $80 \%$ in the free-living herd). Pregnancy lasts from 254 to 272 days $(\bar{x}=264.3, n=132)$. In reserves female bison usually calve for the first time in the 4 th year of life $(\bar{x}=47.8$ months $)$, and earliest in the $3 \mathrm{rd}$ year (33 months of life). Manifestations of oestrus usually last $1-3$ days, the period of repetition of oestrus is $18-22$ days $(\bar{x}=20.6$ days). The calving interval is $10-13$ months for the most fertile cows $(\bar{x}=14.4)$. The reproduction potential does not alter over the whole period of the female's fertile life. The yearly calving rate in reserves is stable, observed range is $63-91 \%$; sterility periods most frequently last one year only. During the sexual activity period each female bison produces an average of 9 calves. Natality rate of the reserve and free-living population does not differ significantly, 77 and $70 \%$ respectively of the mature cows calving annually. In the free-living herd the rate of increase in young was high $(22.4 \%)$ with minimum mortality among calves $(2.3 \%)$. The sex ratio, which was $1: 1$ at birth, changes with age a result of the higher mortality rate among males. Food is a factor controlling, and normal behaviour - stimulating the reproduction in natural populations.

I. Introduction

II. Material and methods

III. Breeding season

IV. Sexual maturation

V. The oestrous cycle

VI. Duration of pregnancy

VII. Evaluation of the fertility of female European bison

1. Age of females at first calving.

2. Number of young born

3. Fertility period and frequency of calving

4. Fertility limiting factors

5. Total increase from a female European bison . 


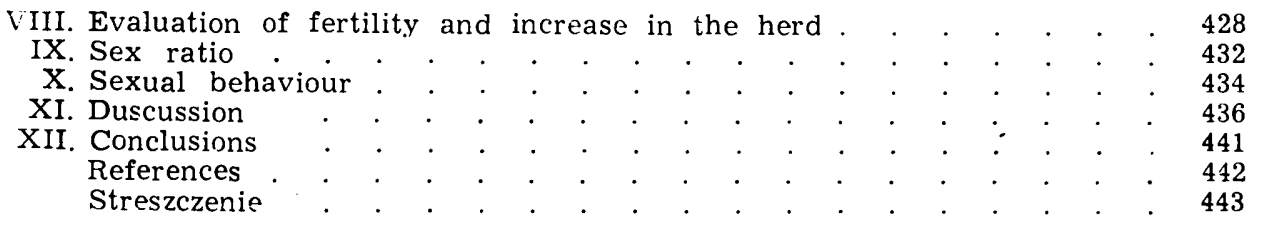

\section{INTRODUCTION}

Relatively little is known of the reproduction of the European bison (or wisent), Bison bonasus (Linnaeus, 1758) ${ }^{i}$ ) under natural conditions. The oldest firsthand information on the biology of this animal, encountered in 19th century literatu$\mathrm{re}$, is fragmentary and not always reliable. Later mongraphs on the Bialowieża and Caucasus bison (K a r c ov, 1903; K u la g i n, 1919; Wr ó ble w ski, 1927; B a ški$\mathrm{rov}$, 1939) refer to populations confined and isolated to an even greater extent, living under conditions widely diverging from natural ones. The effect of human intervention on the European bison was evident in Poland fairly early on (Kry$\mathrm{sia} \mathrm{k}, 1967)$ and led in various ways to changes in the biology of these animals. The greatest effect was exerted by treating the bison as a game animal and by the breeding operations connected with this. The extermination of the European bison in the Białowieża Primaeval Forest put an to the first stage of research on natural population.

The later period of well about fifty years of breeding in enclosures, carried out with considerable intensification of inbreeding under the artificial conditions created in zoological gardens and enclosed reserves, differed fundamentally from the orginal way of life of this animal when it was a free-living species. Its retention in captivity and supervised feeding undoubtedly exerted a great influence on the animal's physiology, including the course taken by reproductive processes (G i l l, 1967).

Many observations on reproduction in the European bison under reserve breeding conditions were made during the research work carried out on elaboration of rational methods for the restitution of this species $(\mathrm{Zablocki}, 1939: 1957)$.

The first study entirely devoted to reproduction in the European bison ( $\mathrm{J}$ aczewski, 1958), is based on data from Polish reserves and information from pedigree books, which covers documentation for the whole period of breeding in reserves up to 1953 inclusive.

The 12-year period of breeding which has elapsed since the completion of those studies seemed to us to be sufficiently long to permit of repeating the analysis of reproduction in bison under the conditions in Polish reserves. In addition 1952 is the year of introduction of a new breeding experiment - the releasing of the herd of European bison, in the Białowieża Primaeval Forest. It is of course obvious that free-living bison live under conditions closer to natural ones, both as regards the effect of the external habitat and of population relations connected with the creation of a spontaneous sccial structure of herds ( $\mathrm{Kr}$ a sińs ki, 1963; 1967). In this way the opportunity was created for the first time since the successful restitution of these animals in Poland of comparing the process of reproduction among European bison living in enclosures with that in free-living bison. Such comparisons would appear to be required now in connection with the new attempts under-

1) The common name "bison" is used throughout the text of this paper in the meaning "European bison" (or wisent). 
taken at breeding the bison under free-living conditions and the necessity for evaluating these experiments from the aspect of restitution the species, Bison bonasus.

\section{MATERIAL AND METHODS}

Use was made in the investigations of data on the reproduction of various cow bison in the four chief breeding centres - at Białowieża, Niepołomice, Pszczyna and Borki, obtained from: (1) the Pedigree book of the European bison 1955-1961, (2) breeding records kept in the various reserves and, (3) notes in observation logbooks kept by assistants.

In principle only the 12 -year period from 1954 to 1965 was covered, taking into consideration all the matings and calvings occurring during this time. All the cow bison which reached maturity during the above period were taken into consideration when assessing fertility. Only in the case of cow bison currently living in the reserve, the fertility season of which extended to earlier years, were all their previous calvings included in the analysis, in order to obtain a full picture of the fertility of the given cow bison.

Documentation and notes on the bison herd living in freedom in the Bialowieża Primaeval Forest (BPF) were used as material for studies of reproduction among free-living bison. Althoug bison were released as early as 1952 the free reproduction of this herd dates from 1958 ( $\mathrm{K} \mathrm{r}$ a s ins $\mathrm{ki}$, 1967). Observations of the free-living herd were continued up to 1966 inclusive. The only information nere was: the composition of the herd in consecutive years as regards sex and age (annual increase in young) and approximate dates of births and the sex of the calves born. It was impossible to obtain data on matings and occurrence of rutting.

\section{BREEDING SEASON}

The seasonal rhythm of sexual furctions in the European bison under natural conditions is not known. In older studies (K a r cov, 1903; Kulag in, 1919: Wroblewski, 1927) the authors were unanimous in emphasing that the natural seasonal character of reproduction had been "upset" as the result of winter supplementary feeding. Under the living conditions in reserves the animal had a sufficient amount of food throughout the whole year. J a czewski (1958) considers as the cause of disturbance of the natural periodic character of reproduction the effect of the hunger factor to which bison were subject at certain times of the year due to the insufficient natural food supply and irregularity of supplementary feeding. As a result the reproduction of bison under reserve conditions most certainly differs from the model characteristic of free-living populations.

The rutting season in reserves takes place during the months from August to December (Table 1) but matings have been recorded in July and also in January. February and March. The largest number of matings occurs in August, September and October. During this period $72.9 \%$ of all matings, which included $70.9 \%$ of all successful matings, were observed. As from November the number of matings decreases gradually, the cases of mating in January, February and March being 
merely sporadic (forming jointly about $7 \%$ of the cases), but they may however be successful. A characteristic phenomenon is the complete absence of oestrus symptoms in cow bison from April to June. Start of pregnancy during this period would lead to the young being born at the most unfavourable period of the winter, from January to March.

An analogical list of effective matings calculated from dates of birth in pedigree books is given by $\mathrm{J}$ a c zew $\mathrm{ski}$ (1958). The sporadic cases of fertilization during the period from April-June given there most certainly occurred in zoological gardens and areas situated in different climatic zones. Under conditions in Polish reserves, as is evident from dates of calving, successful mating did not take place during this period (cf. J a c zew ski, 1958, Tables 7, 8, 9).

Table 1.

Intensity of oestrus manifestations in female bison in reserves.

\begin{tabular}{|c|c|c|c|c|c|c|c|c|c|c|c|c|c|c|}
\hline Month & & $\stackrel{\Xi}{3}$ & సે & $\vec{a}^{\dot{0}}$ & $\begin{array}{l}\dot{0} \\
\stackrel{0}{0} \\
\ddot{\infty}\end{array}$ & $\stackrel{\dot{g}}{8}$ & $\stackrel{\dot{0}}{\mathbf{2}}$ & $\begin{array}{l}\dot{0} \\
\stackrel{\Xi}{ }\end{array}$ & : & $\stackrel{\dot{D}}{\substack{0 \\
k=1}}$ & 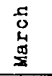 & 竞 & $\frac{\vec{\pi}}{2}$ & $\begin{array}{c}\text { Total } \\
1954-1965\end{array}$ \\
\hline $\begin{array}{l}\text { Number of } \\
\text { copulations } \\
\text { observed }\end{array}$ & $\begin{array}{l}\mathrm{n} \\
\mathrm{x}\end{array}$ & - & $\begin{array}{l}14 \\
2.9\end{array}$ & $\begin{array}{l}92 \\
18.9\end{array}$ & $\begin{array}{l}147 \\
30.2\end{array}$ & $\begin{array}{l}116 \\
23.8\end{array}$ & $\begin{array}{l}51 \\
10.5\end{array}$ & $\begin{array}{l}35 \\
7.2\end{array}$ & $\begin{array}{l}18 \\
3.7\end{array}$ & $\begin{array}{l}9 \\
1.8\end{array}$ & $\begin{array}{l}5 \\
1.0\end{array}$ & - & - & $\begin{array}{l}487 \\
100\end{array}$ \\
\hline $\begin{array}{l}\text { Number of } \\
\text { effective } \\
\text { copulations }\end{array}$ & $n$ & - & $\begin{array}{l}10 \\
4.3\end{array}$ & $\begin{array}{l}48 \\
20.6\end{array}$ & $\begin{array}{l}57 \\
24.5\end{array}$ & $\begin{array}{l}60 \\
25.8\end{array}$ & $\begin{array}{l}19 \\
8.2\end{array}$ & $\begin{array}{l}19 \\
8.2\end{array}$ & $\begin{array}{l}8 \\
3.4\end{array}$ & $\begin{array}{l}7 \\
3.0\end{array}$ & $\begin{array}{l}5 \\
2.1\end{array}$ & - & - & $\begin{array}{l}233 \\
100\end{array}$ \\
\hline
\end{tabular}

Births in reserves are recorded from April to December, but the main calving period is in May, June and July (Fig. 1), during which time $70.9 \%$ of all the calves were born. As from October all the later calvings are sporadic in character, but cases were encountered in all the reserves. $\mathrm{J}$ a c zew ski (1958) gives similar results. The differences consist in the slightly different proportions of calvings in different months: $\mathrm{J}$ ac zewski $(l$. c.) observed a preponderance of birts in May, whereas in the material we examined calvings were distributed fairly evenly over the three peak months. We did not observe any marked differences between the data for the various reserves, and in particular the distribution of births at Pszczyna did not in any way differ from the average picture. Jaczewski (l. c.) explained the shift in births to a later period at Pszczyna by the greater degree of inbreeding of this breeding line or by food differences. The fact that these manifestations disappeared after introducing fresh blood into the reserve following the foot-and-mouth epizootic in 1954 argues in favour of the first assumption.

In the light of results obtained from reserves the course taken by calvings among free-living bison in BPF is interesting. In this connection 
only the birth of young following matings between free-living animals (Table 2) were taken into consideration. The calving season begins in May, and by July inclusively over $80 \%$ of the cow bison had calved. The remaining cows calved in August and September. The calving season in free-living bison was therefore shorter and was limited to the

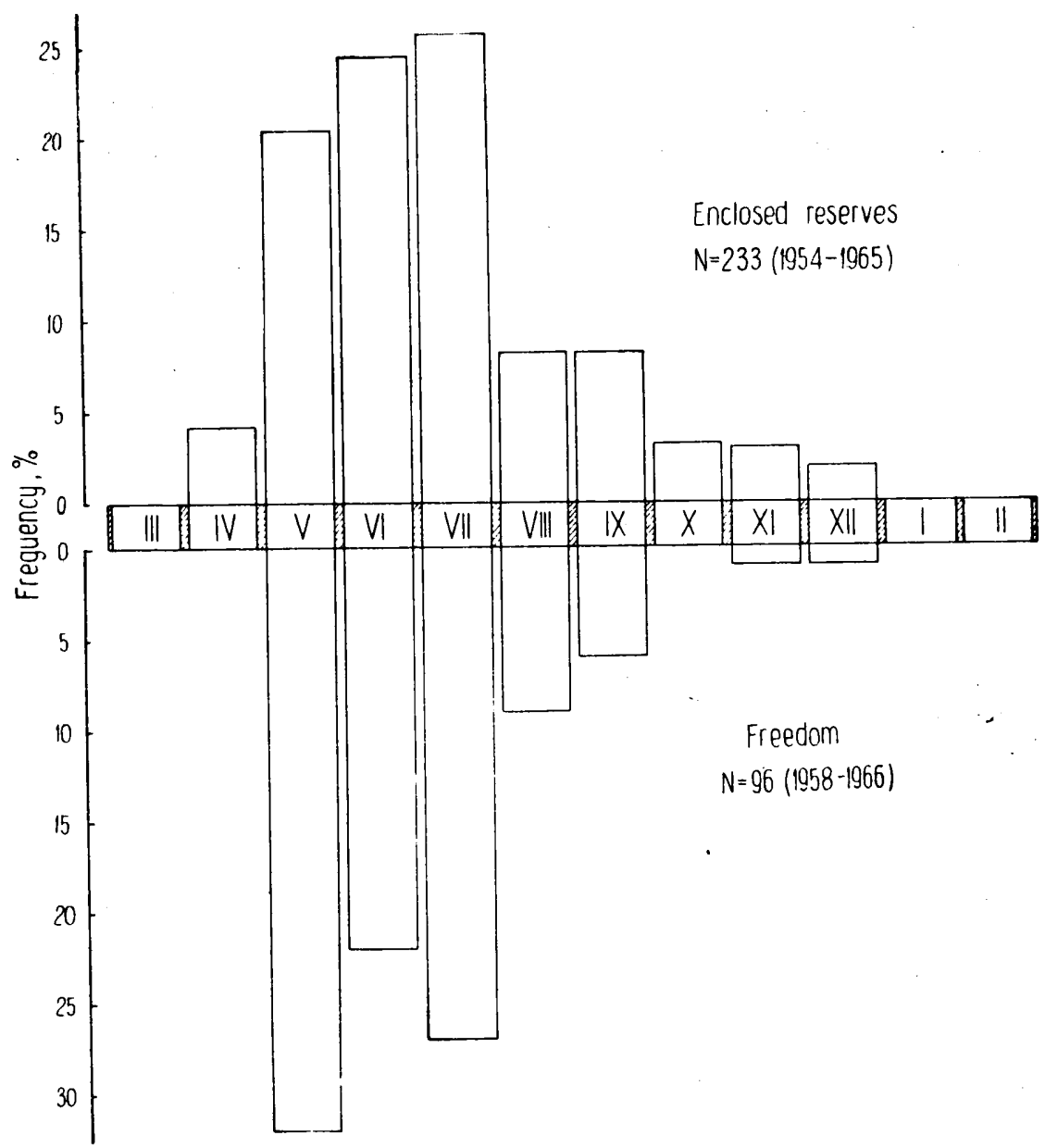

Fig. 1. Comparison of the calving season among female European bison in reserves and those living in freedom.

period from May to September (Fig. 1). The two isolated cases of calves being born in November and December ( $2 \%$ of all births) do not affect. the general rule.

The mating period in the free-living population, determined on the basis of calving, occurs from August to December (not including the 
exceptional cases of mating in February and March). In relation to data from the reserves there is thus a shift in the start of the mating season from July to August, as calving among free-living cows began every year in May. According to earlier authors (B r in cke n, 1829; K a rc.ov, 1903; Wróblewski, 1927; S techow, 1929) rutting among European bison in BPF occurred in August and September, while the calves were born at a period favourable to the species - in May and June. The rhythm was later disturbed as the result of supplementary ieeding. $\mathrm{K} \mathrm{u} \mathrm{lag}$ in (1919) observed calving in BPF during the period from May to November, but says nothing of any births in the winter.

Table 2.

Calving period among female bison living in freedom. ${ }^{*}$ Births among cows covered in enclosures before being released into the forest.

\begin{tabular}{|c|c|c|c|c|c|c|c|c|c|c|c|c|}
\hline Yeaz & 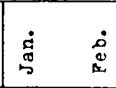 & $\begin{array}{l}\text { f5 } \\
\frac{d}{2}\end{array}$ & $\overrightarrow{\underline{a}}$ & $\vec{\pi}$ & 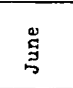 & जे & $\dot{\dot{q}}$ & 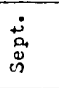 & 总 & $\dot{\vec{\partial}}$ & 离 & Total \\
\hline 1957 & & & & & & $1^{*}$ & & & & & & - \\
\hline 1958 & & & & 2 & & & & & & & & 2 \\
\hline 1959 & & & & 1 & - & 3 & 1 & & $1^{*}$ & & & 5 \\
\hline 1960 & & & & 1 & 2 & 3 & & & & & & 6 \\
\hline 1961 & & & & 2 & 2 & 4 & 1 & 2 & & & & 11 \\
\hline 1962 & & & & 3 & 1 & - & 1 & 1 & & & & 8 \\
\hline 1963 & & & & , & 3 & 2 & 2 & 1 & & & & 13 \\
\hline 1964 & & & & 5 & 2 & 4 & 3 & 2 & & & & 16 \\
\hline 1965 & & & & 4 & 4 & 5 & 1 & - & - & 1 & & 15 \\
\hline 1966 & & & & 6 & 8 & - & - & - & - & - & 1 & 20 \\
\hline Total & & &. & 31 & $2 \varepsilon$ & 26 & 9 & 6 & - & 1 & 1 & 96 \\
\hline$\Phi$ & & & & 32.3 & 22.9 & 27.1 & 9.4 & 6.2 & - & 1.0 & 1.0 & 100 \\
\hline
\end{tabular}

Differences in duration of the breeding season between a free-living population and bison living in reserves leads to the assumption that they depend on the differences in the animals' living conditions. As regards movement and food conditions the extensive forest enclosures of the Białowieża reserve create conditions similar to those in freedorn. During the summer, for instance, the bison often fail to visit the feeding places for a long period, since they find enough food in the large enclosures $(10-80 \mathrm{ha})$. On the other hand, the free-living herd is intensively fed during the winter and during the most difficult period visit the feeding places up to the end of April, without being subject to the hunger factor, which most certainly affected wild European bison. Under such circumstances it would appear that the fact of natural organization 
of the herd is decisive here. Apart from the rutting period the adult males form a separate group, and only join the herd during the mating period (K rasinski, 1967). The sexual selection freely made at that time increases the effectiveness of mating. In this way, by reduction in the number of repeat sexual cycles in the cows, the duration of the inating season in the whole population is simultaneously shortened.

\section{SEXUAL MATURATION}

Breeding records from the reserves show that the time of sexual maturation of cow bison can be established on the basis of the dates of the first calvings and concluding the age of the first effective mating from them. The earliest calving in our material was observed in a cow at the age of 33 months (»Puczaja «1300, Niepolomice, born August 17th 1960 , first calving May 30th 1963). Cow bison begin calving for the first time far more of ten at the age of $35-38$ months, $i$. $e$. at the turning point between tne third and fourth year of live. Thus appropriately for the given periods of calving the dates of the first effective mating come: between the 26th-29th month of life. The cow "Puczaja " was effectively covered at the age 24 months, that is, on completion of the second year of live. J a c z ewski (1958) gives as an extreme case the calving of the cow "Borgia" at the age of 32 months; effective covering must therefnre have taken place when the cow was 23 months old.

Table 3.

Age of females at first calving in breeding reserves.

\begin{tabular}{|c|c|c|c|c|c|c|c|c|c|c|c|c|c|c|c|c|c|c|c|}
\hline $\begin{array}{l}\text { yedr } \\
\text { of life }\end{array}$ & \multicolumn{4}{|c|}{$3 r d$} & \multicolumn{12}{|c|}{$4 \mathrm{th}$} & 5 th & 6 th & Total \\
\hline of $11 \mathrm{fe}$ & $33=$ & 34 & 35 & 36 & 37 & 38 & 39 & 40 & 41 & 42 & 43 & 44 & 45 & 46 & 47 & 48 & $49-60$ & $61-72$ & - \\
\hline $\mathrm{n}$ & 1 & - & 1 & 3 & 4 & 3 & - & 1 & 2 & 1 & 3 & 2 & 1 & 1 & 5 & 5 & 13 & 6 & 52 \\
\hline $\begin{array}{r}\text { Per } \\
\text { cent }\end{array}$ & 1.9 & $-\frac{}{9}$ & & 5.8 & 7.7 & 5.8 & - & 1.9 & 3.8 & $\frac{1.9}{53 .}$ & $\frac{5.8}{9}$ & 3.8 & 1.9 & 1.9 & 9.6 & 9.6 & 25.0 & 11.5 & 100 \\
\hline
\end{tabular}

In our material, out of 52 cases half the cow bison dropped their first calf in the fourth year of live (Table 3 ), but about $1 / 3$ of the cows drop their first calf in their 5 th or 6 th year of life. The mean age of first calving, calculated for the whole material, is 47.8 months $(n=52)$. No distinct differences were observed in the time of sexual maturation of cow bison in different reserves. This indicates that the of attaining maturity is probably an individual characteristic. The distribution of fertility of cow bison which began reproduction early does not confirm 
W r óblewski's (1927) assumption that early calving has a harmful effect on fertility.

There are no systematic observations as to the age at which a cow bison becomes steril. Wrjblewski (1927) assumes that the Białowieża bison become exhausted early on, and only produce from 7-8 calves during their lifetime. Data from reserves include the interesting case of the cow »Beste " 524, which calving regularly produced its last calf at the age of 19 , after which it was steril until it died at the age of 24 years. The cows "Podwika " 736 and "Poświata " 740, althoug 17 years old, were observed to lead calves in 1965. Bearing in mind however that conditions are more favourable in reserves it may be assumed that the fertility period of cow bison is shorter under natural conditions.

It is difficult to define the age at which male bison attain sexual maturity since males are as a rule allowed to cover cows at an age of over 3 years. The male bison "Pokorny" used for cross-breeding with domestic cattle, successfully covered a cow at the age of 31 months. Cases of early successful mating given by $\mathrm{Z} \mathrm{a} \mathrm{blocki}$ (1949) and I ac zew ski (1958) point to the possibility of the males attaining reproductive capacity at the age of $15-20$ months of life. Ka r cov (1903) defines this moment at the 3-4 year of life, Wróblewski (1927) gives the figure of 5 years. Histological examination of testes of 2 and $2^{1 / 2}$ year old male Białowieża bison revealed the absence of spermatozoa. The late sexual maturity of Białowieża male bison, in W róblewski's opinion, is connected with the poorer food conditions in the Forest; the Caucasus bison mature earlier according to him. After attaining sexual maturity, however, the male bison are capable of reproduction until very old, spermatogenesis being absent only in old males exhausted by disease.

Under natural conditions the time at which the male begins reproduction is not of course determined by the moment of physiological maturity, but by intrapopulation factors connected with the social hierarchy of the herd. In a free-living population the adult males over the age of $4-5$ usually live alone throughout the greater part of the year. During the rutting period they join the herd of females and young bison and prevent the younger males from covering females ( $\mathrm{K} \mathrm{r}$ a siń ski, 1967). The oldest bulls are also prevented from mating. $\mathrm{Kulag}$ in (1919) observed weakening of the sexual functions in males as early as the 10 th year of life, when some of them left the herds and continued living alone. Observations in reserves show that bull bison continue to cover cows efectively up to the age of 15 years. Old males do not manifest suxual excitement. 


\section{THE OESTRUS CYCLE}

Manifestations of oestrus in a female European bison, particularly at the initial phase, are not characteristic. Practically speaking oestrus is discovered only on the basis of the animals' behaviour in the presence of the bull. During the initial period the male sattends" the female, mating taking place in the second phase (cf. Section X). According to our data taken from keepers' observations (chiefly in the Niepolomice reserve) visible manifestations of heat occurred most often from 1 to 3 days $(\mathrm{N}=54, \overline{\mathrm{x}}=2.6$ days), while longer periods were sporadically recorded (up to 7 days). J a c z e w ski (1958) states that the period of "attendance " most often lasts one day. Copulation was observed at various times of the day, and often take place twice or more in a day. The phase of the oestrus during which the female allows the bull to cover it may last $2-3$ days.

The oestrus cycle in female European bison takes place in a way similar in many respects to the well-known relations in domestic cattle. A cow which is not fertilized repeats the oestrus until it becomes pregnant. The successive appearances of oestrus in female bison are easy to grasp among animals kept in an enclosed area, since during the rutting season the breeding herd always includes a sexually active male, which is roused by the occurrence of oestrus in a female to cover it. It is worthy of note that from April to June only one case of heat and mating was recorded in Polish reserves, in the reserve at Gorce (the female "Pupilka " on April 11th 1952), where the breeding conditions in fact differed from those in other Polish reserves (cf. J a c zew ski, 1958 Tab. 10). The data presented prove that a period of anoestrus in April, May and June, occurs during the reproductive cycle of female bison. Under natural conditions anoestrus was probably even more distinctly marked and most probably included the whole winter and spring period, as is shown by the low percentage of matings in January, February and March. J a c z e w sk i's opinion (1958) that oestrus in female bison may be repeated throughout the whole year is inaccurate in relation to animals bred in Polish reserves, that is, in the climatic zone proper to this species. This does not apply to males, which are probably distinguished by constant reproductive capacity. For instance, the male bison "Pokorny" used for cross-breeding with domestic cattle covered cows of the Lowland Black-and-White and Polish Red breeds several times in April, May and June. The fact that none of these matings were effective is almost certainly connected with the difficult conception in domestic cows covered by a male European bison ( $\mathrm{K} \mathrm{r}$ a s i n s k a, 1963). 
Sporadic cases may occur of copulation during pregnancy, usually during the first period after fertilisation, and in such cases the date of effective covering can be determined exactly by knowing the time of calving and average duration of pregnancy. A certain degree of anomaly was found in two female bison in the Niepolomice reserve. The cow bison "Pulka " and "Puźnianka " permitted copulation up to 3-4 days before calving. Considerable variation is observed in the length of the oestrus in female bison, due partly to the deficiencies in observation methods, but probably also partly due to the season of the year, food conditions, the animal's condition etc. In order to obtain reliable data only material relating to a period of $10-30$ days was taken into consideration. Shorter repeats of oestrus were only sporadically recorded, but longer periods occurred more often. In some cases the interval between two consecutive appearances of oestrus was fairly exactly equal to the multiple of the

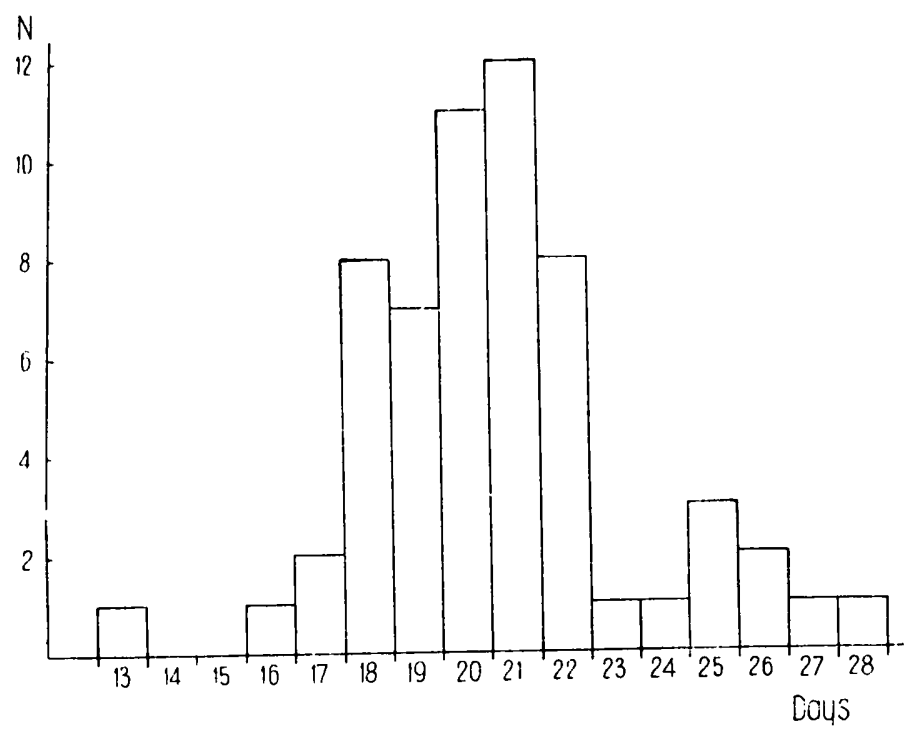

Fig. 2. Frequency of repetition of oestrus in female bison.

normal sexual cycle, which indicates that one or more oestral periods were omitted from the records. Some of the cases might have been due to recording disturbances in the sexual cycle. Material originating chiefly from the rescrve at Niepolomice is set out in Fig. 2. With a range of variation from $12-28$ days almost $80 \%$ of the cases come within limits of 18 to 22 days, while the average length of the cycle is 20.6 days.

According to $\mathrm{J}$ a c z e w s k i's data (l. c.) female bison most often repeat oEstrus at intervals lasting about 20 days, although this period is often variable in different cows. 
'The observation that the oestral cycle exhibited considerable constancy in the group of cows which conceived in the given year merits emphasis. In the group of sexually mature female bison which ended the rutting season sterile, the sexual cycles most often took a somewhat irregular course and there were long intervals in it.

Occurrence of first oestrus following parturition forms one of the factcrs regulating the seasonal character of reproduction. In our material we found that the shortest time which elapsed between calving and occurrence of post-parturition oestrus was 13 days. This occurred in the bison cow "Pociecha " 909, which calved on July 9th 1961, and was covered on July 22nd 1961. A very short period of 23 days was also found in this same female in 1960. The gaps in documentation made it impossible to check up on this in all of the females. It is only on the basis of duration of periods between different calvings that it is possible to draw conclusions indirectly as to the time at which post-parturitional oestrus takes place in the reserve population. Bearing in mind the fact that the first copulation rarely proves effective, it may be assumed that oestrus appears relatively soon after giving birth in a high percentage of females. Effective covering took place in relation to $6.2 \%$ of the females during the first month after calving (the interval between consecutive calvings did not then exceed 10 months). As many as $15.6 \%$ of the females were covered during the period of two months after parturition. In all $45 \%$ of the female bison become pregnant during the first three months after calving.

In older literature it is only $\mathrm{Ka} \mathrm{rcov}(1903)$ who mentions that in the Białowieża Primaeval Forest oestrus occurs in female bison from 4-5 months after calving. $\mathrm{J}$ a c z e w s ki (l. c.) gives the periods of 22 and 25 days after giving birth as the earliest cases of cccurrence of post-parturitional oestrus, copulation proving effective in the first case. $\mathrm{He}$ also found that under reserve conditions oestrus occurs in females most often within $40-80$ days after calving. In theory, in order that the cyclic character of reproduction may be maintained, post-parturitional oestrus should appear about 100 days after giving birth. A tendency to earlier appearance of post-parturitional oestrus may, in our opinion, be treated as a visible manifestation of domestication. This phenomenon is certainly connected with the effect exerted on the female bison's organism by food factors.

\section{DURATION OF PREGNANCY}

In older literature on the European bison the duration of pregnancy was almost unanimously given by different authors as about 9 months (Brincken, 1826; 
K a r cov, 1903; Kulagi n, 1919; Wróblew ski, 1924; B a škirov, 1939) both for the Bialowieża (Lithuanian) and Caucasian subspecies. It only became possible to obtain accurate data under enclosure conditions by means of recording copulations and calvings. K a lug in (1958) defined the duration of pregnancy in a herd of cross-bred European and American bison in the Caucasus in this way as 261283 days. Zablocki (after Geptner et al., 1961), on the other hand, gives this period as $262-267$ days.

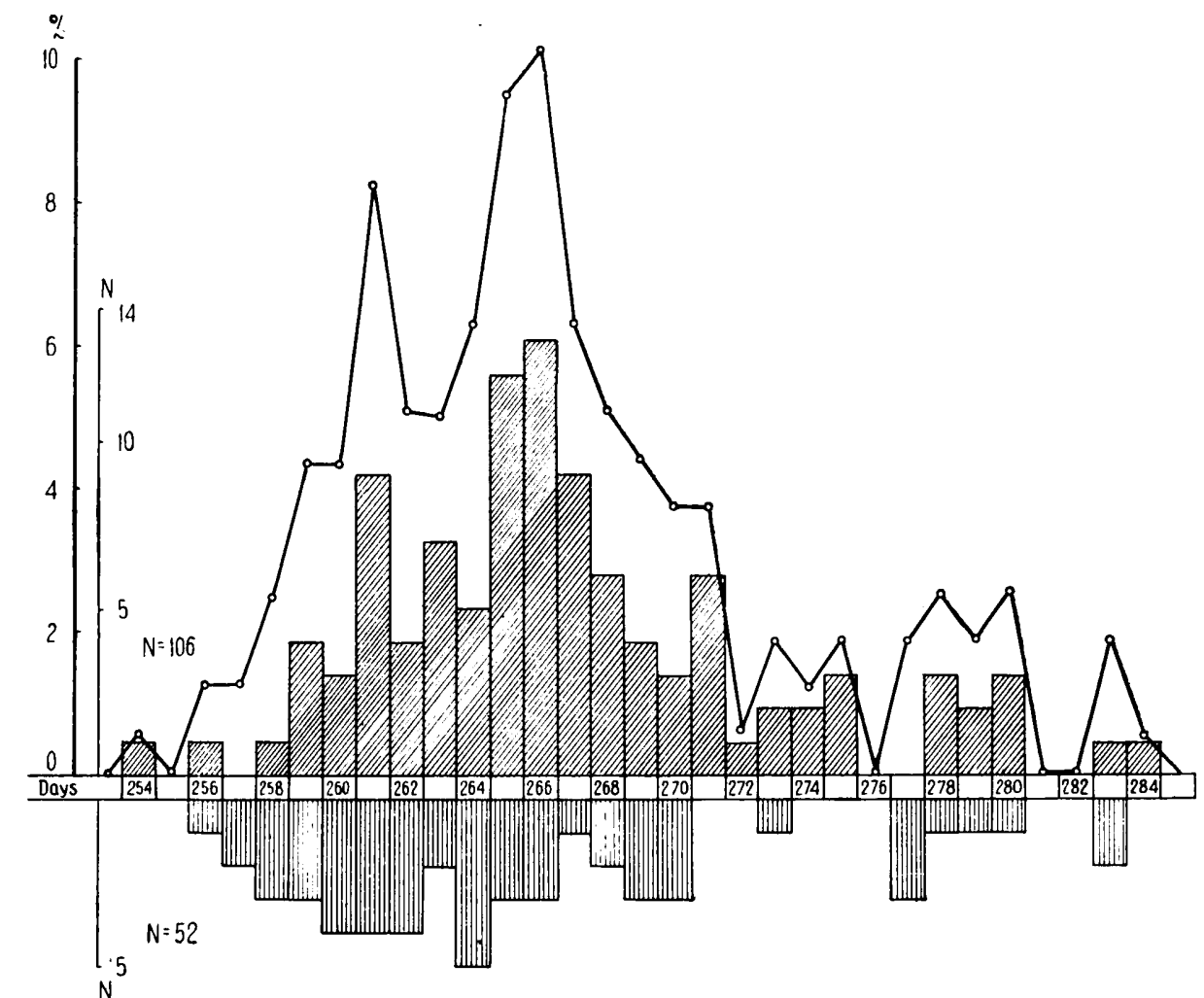

Fig. 3. Duration of pregnancy.

At top - autors' own data, at bottom - data taken from the study by $\mathrm{J}$ a c z ewski (1958), from tables X-XII. The curve illustrates the distribution of frequency for the whole of the material $(N=158)$.

In the present investigations it was chiefly data from Niepołomice reserve which were used to define duration of pregnancy. Calculation of duration of pregnancy was made on the basis of the difference in time between the last registered (effective) covering of the female bison and date of calving. In addition to the authors' own material the data given by J a czewski (1958) were also used, assuming that these observations are in principle uniform (documentation of reserves). Bearing in mind the possibility that the final copulation may not be observed 
it is necessary to take into consideration the possibility that a certain percentage of the data in the material may be incorrectly high. It is therefore necessary to take a critical view of the material.

The range of duration of pregnancy obtained from 254 to 284 (30 days) would appear improbably wide for a wild animal (Fig. 3). It is sufficient for purposes of comparison to mention that even for breeds of cattle varying greatly physiologically duration of pregnancy is from 278-290 days (A s d e l l, 1946), and only in a few breeds lasts as long as 311 days (S tudiencov, 1956). In this case however the difference between extreme values is not more than 20 days. The distribution of the cases investigated deflects sharply in the 272-day class of pregnancy duration, and it may therefore be assumed that the limits of maximum duration of pregnancy in the European bison runs close to this value. Longer periods up to the maximum are caused by the failure to record the final copulation. Both the sporadic and irregular character of occurrence of such cases points to this, and also the fact that they are separated from the lowest values by an interval of $17-20$, days that is, a period coming within the limits of cycle lenght in the female bison. The possibility cannot be ruled out, however, on the basis of the character of distribution of numbers (cf. Fig. 3), that both erroneous data due to failure to observe the final covering, and real extreme durations of pregnancy may be contained within the class of 271-275 days. An agreed limit of 272 days was accepted for further calculations as the maximum value.

Duration of pregnancy in female bison therefore varies from 254 to 272 days with average value of $264.29 \pm 4.20$ (confidence interval 0.72 , $\mathrm{N}=132$ ). This result introduces a correction on the basis of a greater amount of material. to the data given by J a czewski (1958), who stated that duration of pregnancy in the female bison varies from 260 to 270 days (average 265 days). [ $N$. $b$. for whole range of data quoted by $\mathrm{J}$ a c zew ski ( $256-280$ days) the average calculated is 265.8 days].

\section{EVALUATION OF THE FERTILITY OF FEMALE EUROPEAN BISON}

The fertility of the females is a particularly important element in the restitution of the European bison, yet it has never formed the subject of special analysis. The reason for this state of affairs is most certainly that in none of the work so far carried out with European bison is there any noticeable tendence to selection based on basic breeding observations. An additional factor here is formed by the difficulties of a methodical nature connected with the semi-wild character of breeding European bison.

The age at which the female first gives birth and later regularity of calving in successive years are the most important factors affecting the fertility of female bison. $\mathrm{Z} \mathrm{a} \mathrm{blocki}$ (1957) takes these factors into consideration, defining the fertility 
of different cows in percentages: cows which calved every years from the fourth year of their lives until their death have $100 \%$ fertility. The percentage of fertility may even exceed 100 , if the first calving occurs earlier. For practical purposes this method is not convenient, as it can only be defined ex post in comparative evaluations, and in addition only for females which lived for, at least, the average life span of these animals.

Severcov $(1940 ; 1941)$ takes significant factors affecting the fertility of females into consideration by introducing the so-called reproductive rate. When estimating the fertility of a population Severcov (1941) includes, for instance, the age at which the fernale first gives birth (age of maturity), the number of calves born during a year and the period elapsing between two births. For a complete analysis of effective fertility it would only be necessary to add here an evaluation of progeny from the aspect of healthiness and capacity $f(r)$ survival. The picture of fertility of female European bison given below refers to animals living in Polish breeding reserves over the period of the last 10 years under relatively stable conditions.

\section{Age of first calving}

In this question we are concerned with the estimation of two values in the population aspect: (1) the age at which the female bison can produce progeny for the first time and (2) the time from which most of the female bison in a population can be treated as "breeding ". Both these values must be expressed in calendar years of the female bison's iife on account of the convenience of such treatment in breeding practice.

Table 4.

Ratio of female bison which have calved to the total number capable if reproduction depending on calendar age.

\begin{tabular}{|c|c|c|c|c|c|}
\hline $\begin{array}{l}\text { Per cent of females: } \\
\qquad / n=51 /\end{array}$ & 2 & $\begin{array}{c}\text { lend } \\
3\end{array}$ & $\begin{array}{r}y \\
4\end{array}$ & $\begin{array}{l}x \text { of } \\
5\end{array}$ & $\begin{array}{c}11 \mathrm{fe} \\
6\end{array}$ \\
\hline $\begin{array}{l}\text { calving for the first time } \\
\text { considered capable of } \\
\text { reproduction }\end{array}$ & - & $\begin{array}{l}27 \\
27\end{array}$ & 44 & $\begin{array}{l}21 \\
98\end{array}$ & $\begin{array}{l}2 \\
100\end{array}$ \\
\hline
\end{tabular}

Definition of the second moment presents a problem, as the only criterion of attainment by the female of sexual maturity is its first calving. For this reason all cow bison which had given birth to their first calf were considered capable of reproduction, regardless of whether they were in calf at the time of examination or sterile (Table 4).

It may be assumed that as from the fifth calendar years of life all the cows in a breeding population shculd participate in reproduction, but for all calculations of an estimative character the mean age at which the first calving takes place, during the first calendar year of the females' life, should be used ( $\overline{\mathrm{x}}=47.8$ months) (Table 3 ). 


\section{Number of young born}

No case of twin pregnancy occurred during the study period, neither were cases of twins encountered in the Bialowieża Primaeval Forest by either Brircken (1826) or $\mathrm{Karcov}$ (1909). According to W róblewski (1927) and Pfitzenmayer (1929) twin calves were occasionally born both at Białowieża and among the Caucasian bison: $\mathrm{W} \mathrm{r}$ ó ble wski describes a case which he himself saw of the birth of twin sister calves. Another case confirmed by documentation is the birth of still-born twin calves at Pszczyna reported by $\mathrm{Mohr}$ (1952). More recently another case of twin calves being born occurred at Sierpuchow cn July 1st 1960, to the cow "Mołnija « 838 (Pedigree book 1961) and twin pregnancy in the herd living in the Caucasus ( $\mathrm{K} \mathrm{al} \mathrm{ug} \mathrm{in}$, in lit. ).

The birth of twin calves need not therefore be taken into account as a factor affecting fertility in European bison.

\section{Fertility period and frequency od calving}

The fertility period in the life of the female bison, beginning in the 3 rd - 5th years of life, lasts until the animal reaches late old age. Its length is determined to a great degree by the longevity of the female. In the series of cow bison examined all the animals in the 17 year old class $(n=6)$ were still fully fertile (Fig. 4). The cow "Beste " 524 gave birth to her last calf at the age of 19 , then remained sterile until her death at the age of 24 . The cow "Kauka" described by M o h r (1952) as very fecund, calved for the first time at the age of 4 and then produced 20 calves over a period of 21 years (1925-1945), thus being sterile in one year only. Her last calf was born when she was 24 . In the breeding practice of the Central European Bison Reserve of the USSR the age at which the final calving takes place (end of the fertile period) was taken as 19 years $(\mathrm{Z} \mathrm{a} \mathrm{b} \mathrm{loc} \mathrm{ki,1957)}$ on the basis of many years experience in planning herd increase, excluding cows aged 20 years or over from the reproducing group.

It remains to explain the characteristics of fertility in female bison over the whole fecund period. According to our data (Fig. 4), as from the 5th year of life, when practically speaking all the females enter the reproducing group, the percentage of calving females remains steady within limits of $72-85 \%$. From the time the cow bison attains sexual maturity its reproductive potential is therefore as a rule maintained on an unvarying level until the reproductive functions cease. The age factor in females should not therefore be taken into consideration when estimating the frequency of calving during the fecund period. The age 
of the female does not affect the quality of its progeny, since no differences were found in the mortality of calves depending on the age of the female bison ( $\mathrm{Zablocki}, 1957)$.

In $\mathrm{Za} \mathrm{blocki's}$ opinion (1957) the number of calves obtained from a female show a peak at the age of 4 years and decreases with age. This view, however, is based on erroneous interpretation of results, the diagram referred to in support of this opinion only constituting a picture of te age structure of reproducing females.

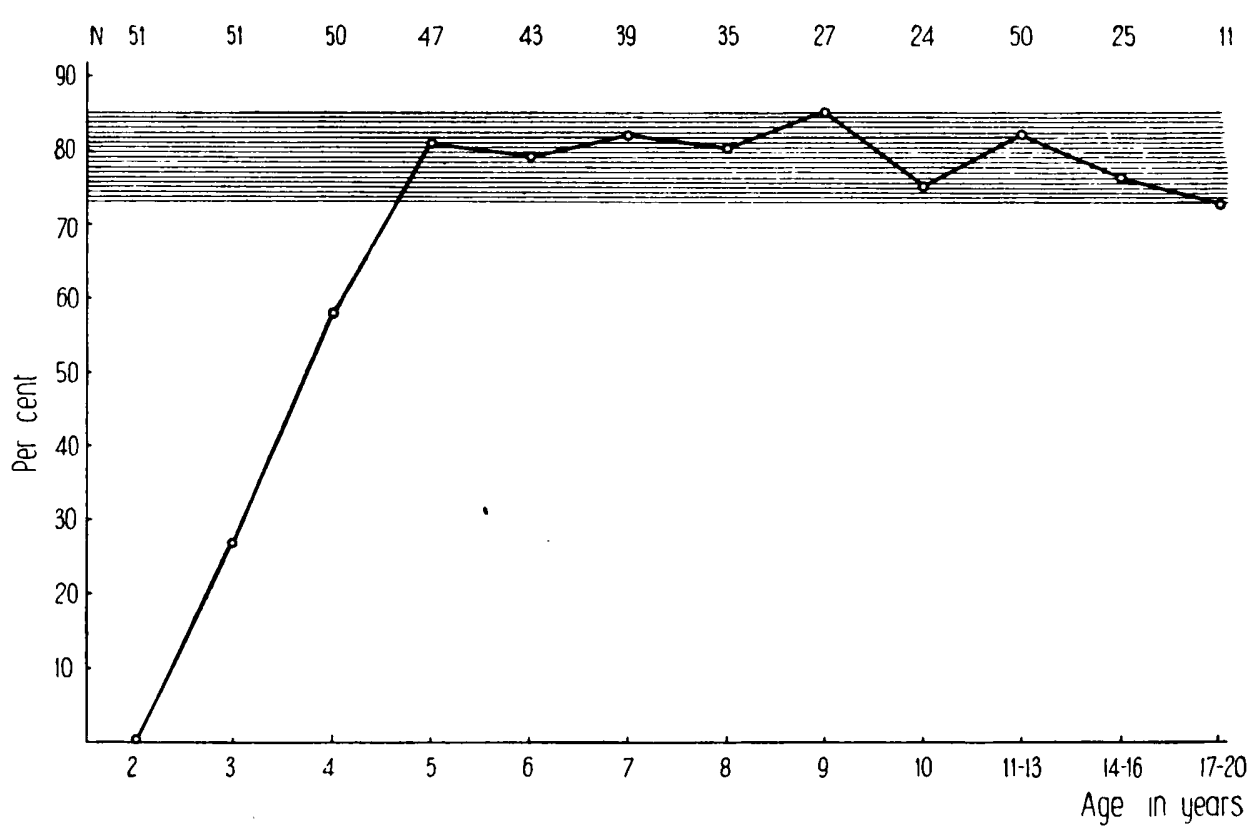

Fig. 4. Fertility index in female bison depending on age.

In theory a female bison is capable of calving each year throughout the whole period of fertility. In reality recorded facts of similar fecundity are only those in the cases of the cow "Kauka " or "Plakette" ( $M$ o h r, 1952). In breeding reserves periodical occurrence of sterile years is the rule among the majority of female bison. Under natural conditions sterile periods occurred more intensively. Female bison from natural populations in BPF were held to calve once every $2-3$ years at most (Ka r cov, 1909; Kula g in, 1919; W r ó b l ew s k i, 1927).

Considerable frequency and regularity of calving forms a characteristic feature of the most fecund cow bison. Utilization of these facts for estimating fertility is possible thanks to the use as index of the mean calving interval. Almost half the births $(45.8 \%)$ take place successively 
at intervals of $10-12$ months. Longer periods point to an absence of regularity in calving, although intervals of one year can still be considered regular. It is the longer periods, from 18-19 months, which indicate a lack of calving in one or two consecutive calendar years. In the group of female bison (excluding cases of permanent sterility) the mean interval between calvings was 14.4 months (Fig. 5), but is most often from $11-13$ months $(55 \%)$.

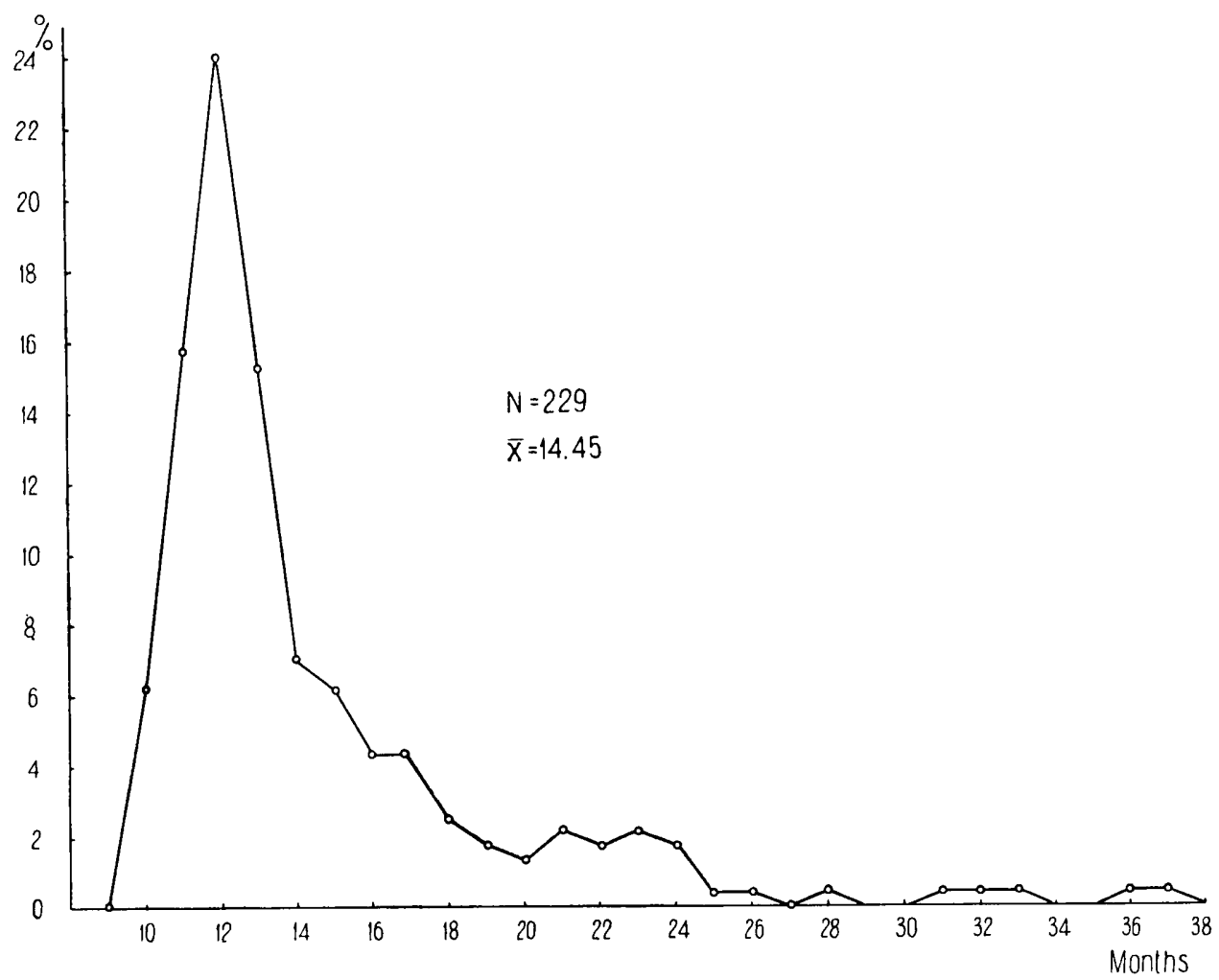

Fig. 5. Duration of calving intervals in female bison in reserves.

Table 5 gives a comparative estimate of the fertility of all the female bison studied. The individual mean calving intervals were calculated here for older cows, which had reproduced longer (over 5 calvings), and were found to vary between 11.8 and 22.5 months. One-year periods (calendar) predominate among the various intervals between calvings, and form $16.4 \%$ of the total potential calvings. Two-year intervals in reproduction occurred only 4 times $(2.4 \%$ of potential calvings). Periods of more than two years of sterility are connected with permanent sterility of the female. 
Table 5.

Table of fertility of female bison in breeding reserves. The fertility $(+)$ and sterility ( - ) of female bison is given in the table for the study period, from the time of first calving until the end of observations, due to: death of the female (M), its relase into the forest (R) or transfer to a zoo (ZOO). Mean calving intervals calculated only for older cows, taking into consideration the whole fertility period of the cow. 1) - not covered, 2) - died with foetus in uterus, 3) - abortion 4 ! verv fat.

\begin{tabular}{|c|c|c|c|c|c|c|c|c|c|c|c|c|c|c|c|c|c|}
\hline \multirow{2}{*}{\multicolumn{2}{|c|}{$\begin{array}{l}\text { Pedegree No } \\
\text { \& Name }\end{array}$}} & \multirow{2}{*}{$\begin{array}{l}\text { Year } \\
\text { of } \\
\text { b1rth }\end{array}$} & \multirow{2}{*}{ 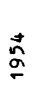 } & \multirow{2}{*}{$\stackrel{\tilde{n}}{\sigma}$} & \multirow{2}{*}{$\stackrel{\mathscr{n}}{\sigma}$} & \multirow{2}{*}{$\stackrel{\tilde{\alpha}}{\sigma}$} & \multirow{2}{*}{$\stackrel{\infty}{\alpha}$} & \multirow{2}{*}{ مू } & \multirow{2}{*}{\multicolumn{2}{|c|}{ 。 }} & \multirow{2}{*}{ 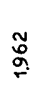 } & \multirow{2}{*}{$\stackrel{5}{\circ}$} & \multirow{2}{*}{ 苛 } & \multirow{2}{*}{$\stackrel{\hat{\alpha}}{\sigma}$} & \multirow{2}{*}{$\stackrel{\circ}{\circ}$} & & $\begin{array}{l}\text { ang } \\
\text { rval }\end{array}$ \\
\hline & & & & & & & & & & & & & & & & N & Avg. \\
\hline 524 & ARSTE & 1939 & - & + & + & + & + & - & - & - & - & M & & & & 8 & 15.0 \\
\hline 596 & 5 PUTKA & 1942 & + & + & + & + & - & + & $-1 /$ & $-1 /$ & u & & & & & 9 & 14.3 \\
\hline 723 & 3 PUZOMKA & 1947 & + & + & + & + & + & + & $-z c$ & 200 & & & & & & 8 & 12.1 \\
\hline 724 & PUSZYNKA & 1947 & + & + & + & + & + & + & - & + & - & $M$ & & & & 8 & 14.1 \\
\hline 725 & 3 PUBORKA & 1947 & + & + & + & + & + & + & + & + & + & + & + & - & & 13 & 12.2 \\
\hline 736 & 5 PODWIKA & 1948 & + & + & + & + & + & + & - & + & - & $-1 /$ & + & + & - & 9 & 14. 3 \\
\hline 737 & 7 PLAMKA II & 1948 & - & + & + & + & + & + & +1 & + & + & + & + & $\mathrm{R}^{2}$ & & 11 & 13.4 \\
\hline 740 & POSHIATA & 1948 & + & + & + & + & + & + & + & + & + & + & + & + & $\mathrm{R}$ & 12 & 12.4 \\
\hline 748 & B PULIANKA & 1948 & + & + & + & + & - & + & +1 & + & 200 & & & & & 6 & 15.5 \\
\hline 760 & POZORKA & 1949 & + & + & + & + & - & + & + & + & + & + & + & + & & 11 & 14.6 \\
\hline 770 & POPIELICA & 1949 & + & - & + & + & + & + &.+ & + & M & & & & & 7 & 13.8 \\
\hline 790 & PUSZCZANKA & 1950 & + & + & + & - & + & + & + & + & + & + & - & + & - & 9 & 13.8 \\
\hline 791 & PULKA & 1950 & + & + & + & + & + & + & 200 & & & & & & & 4 & 12.5 \\
\hline 795 & 5 PURTANKA & 1950 & + & - & + & - & + & + &.+ & + & + & 200 & & & & 6 & 15.5 \\
\hline 812 & PORESA & 1951 & & & + & + & $\mathrm{R}$ & & & & & & & & & & - \\
\hline 819 & PUDLARKA & 1951 & & & & + & + & + & $+z$ & 200 & & & & & & & - \\
\hline 823 & PULONKh & 1951 & & + & + & - & + & + & 200 & & & & & & & & - \\
\hline 827 & POGON & 1951 & & & + & + & + & + & $\mathbf{R}$ & & & & & & & 3 & 13.3 \\
\hline 831 & РОZХOTA & 1951 & & + & + & + & + & - & +-1 & - & + & + & + & - & $\mathrm{R}$ & 7 & 13.3 \\
\hline 832 & POLATUCHA & 1951 & & + & - & $+3 /$ & +3 & + & + & - & + & A & & & & 3 & 16.8 \\
\hline 850 & POBUDKA & 1952 & & + & + & - & + & + & $-z c$ & 200 & & & & & & & \\
\hline 903 & PUSTELNIA & 1953 & & & + & - & + & + & + & - & + & + & + & + & - & 7 & 15.3 \\
\hline 909 & POCIECHA & 1953 & & & + & - & + & + & & + & - & - & - & - & $-4 /$ & & - \\
\hline 911 & PUZNIANKA & 1953 & & & & + & + & + & 200 & & & & & & & & - \\
\hline 912 & KAMIONRA & 1953 & & & & & + & + & + & + & + & - & + & $\mathbf{R}$ & & 5 & 14.2 \\
\hline 935 & PONITA & 1954 & & & & & & + & - & - & + & - & + & - & & & - \\
\hline 937 & PUכZKA & 1954 & & & & & + & - & & + & + & + & - & + & & 4 & 20.0 \\
\hline 939 & POLANKA & 1954 & & & & & +3 & + & - & + & - & - & + & + & - & 4 & 22.5 \\
\hline 941 & PUSLONKA & 1954 & & & & & & + & + & + & + & + & + & + & & 6 & 11.8 \\
\hline 973 & PULESSIAA & $195: 5$ & & & & & + & + & & - & - & - & $\mathrm{R}$ & & & & - \\
\hline 975 & POKUSA & 1955 & & & & & + & + & - & + & + & - & + & $\mathrm{R}$ & & 4 & 15.5 \\
\hline 977 & POHAGA & 1955 & & & & & $\because$ & + & - & + & - & u & & & & & - \\
\hline 979 & PURELIA & 1955 & - & & & & & + & - & + & - & - & + & + & & & - \\
\hline 1021 & PUSKALKA & 1956 & & & & & & + & & + & + & + & + & + & & 6 & 11.8 \\
\hline 1030 & PUCURKA & 1956 & & & & & & & +1 & & + & + & + & + & + & 6 & 12.0 \\
\hline 1070 & PUTNIA & 1957 & & & & & & & & - & + & + & - & + & & & - \\
\hline 1131 & KANIA & 1958 & & & & & & & & + & + & + & + & + & + & 5 & 11.8 \\
\hline 1136 & POCHMURNA & 1958 & & & & & & & & & + & + & + & + & + & 4 & 12.5 \\
\hline 1141 & PUJANKA & 1958 & & & & & & & & & + & $\mathrm{R}$ & & & & & \\
\hline 1143 & PORECZNA & 1958 & & & & & & & & & & + & + & + & + & & - \\
\hline 1294 & PLISZKA II & 1959 & & & & & & & & & & + & - & + & + & & - \\
\hline 1205 & PUSTALKA & 1959 & & & & & & & & & & & + & + & + & & - \\
\hline 1206 & POTEGA & 1959 & & & & & & & & & & + & + & + & + & & - \\
\hline 1232 & PUZONKA & 1959 & & & & & & & & & & & + & + & & & \\
\hline 1284 & PLBNNA & 1960 & & & & & & & & & & & & 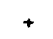 & $-1 /$ & & \\
\hline 1293 & PUCERTA & 1960 & & & & & & & & & & & + & + & + & & - \\
\hline 1300 & PUCZAJA & 1960 & & & & & & & & & & + & R & & & & \\
\hline 1303 & PURORA & 1960 & & & & & & & & & & & + & 200 & & & \\
\hline 1356 & PLAGA & 1961 & & & & & & & & & & & & & - & & \\
\hline 1357 & PLATYNA & 1961 & & & & & & & & & & & & & + & & \\
\hline 1357 & PLATETA & 1962 & & & & & & & & & & & & & + & & \\
\hline
\end{tabular}


The following three factors: time of first calving, number of calves born in relation to the number of fertile years and regularity of calving (length of calving interval) must be taken into consideration in order to determine which female has maximum fertility. It is primarily older female bison which have already produced a large number of calves which should be allocated to this group, i.e.: "Puborka « 725, "Poświata" 740 , »Plamka II « 737, »Puzorka« 760, »Puszczanka 790 and »Pułomka« 723. Of the younger cows "Kania« 1131, »Pusłonka« 941, »Puskałka" 1021 and "Pucułka " 1030 calve very regularly ( $\overline{\mathrm{x}}$ period between calvings $11.8-12.0$ ), and promise to prove good breeding material.

A characteristic feature of highly fertile females is the fact that they attain sexual maturity relatively early (they usually calve as early as the 3rd calendar year of life) and are then distinguished by considerable regularity and normal course of the reproductive processes. All the female bison which produced larger numbers of calves exhibit a low value for the calving interval. These observations may form some confirmation of the opinion that the fertility of these females may constitute. their individual characteristic.

\section{Fertility limiting factors}

The phenomenon of periodical sterility is a more or less normal in the female bison. Under reserve conditions it may be taken as a rule that about $20 \%$ of the females in the group of fully mature animals will not calve. There are some causes of this state.

Table 6.

Effect of the time of calving on sterility of female bison the following breeding season.

\begin{tabular}{|c|c|c|c|c|}
\hline Wonth of calving & Sept. & oct. & Nov. & Dec. \\
\hline $\begin{array}{l}\text { No. of females which calved } \\
\text { outside the ma1n calving pertod, } \\
\text { and } \\
\text { were sterile the following season }\end{array}$ & 16 & 8 & 4 & $\begin{array}{l}5 \\
5\end{array}$ \\
\hline
\end{tabular}

The capacity of the female bison to conceive probably decreases together with the shift of the final calving outside the main calving period. Among the female bison analysed which calved during the period from September to December the majority were sterile during the following season (Table 6).

Bearing in mind that the principal period of oestrus in European bison occurs during the months from August-October (which corresponds to calving from May to July) belated calvings in November and December 
are the result of copulation taking place outside the true rutting season. The fact that such copulation does not then result in fertilisation may be due primarily to the failure of post-partum oestrus to appear in the female, and as a result the cow is not covered until the next rutting season, and thus there is a pause in reproduction for one year.

The death of the calf may be a cause of transistory infertility in the female. This fact, observed in reserves, was confirmed by us in the case of available female bisons which either gave birth to dead calves, or were deprived of their calf a short time after calving, during the period of intensive lactation. Among 19 such cows - $8(42 \%)$ became sterile the following year, but in the group of adult females (from 5th year of life) whose calves lived through the lactation period, sterility occurred in only $17 \%$ of the cases out of 281 possible calvings. This comparison demonstrates the important effect that the calf's death has on sterility the following year, although such a result is by no means the rule. The mechanism of this phenomenon is undoubtedly based on disturbances in the processes of hormonal regulation in the lactating cow.

A separate group is formed by those cases of infertility which cannot be explained as due to a definite cause, althought they occur with considerable intensivity. In breeding enclosures permanent sterility in a bull is easy to perceive, as the same male usually covers several cows, of ten at short intervals. In our material it was only once that we met with a case of a female being sterile as the result of using a sterile male. It must be assumed that the total number of cases of infertility include cases of sterility due to loss of the embryo during the early stages of embrionic development (cf. data for cattle $-\mathrm{N}$ a l b a n d o v, 1958).

It was found that frequently prolonged sterility, cases of abortion or dropping low-vitality calves occur more often in some females than in other. Such females can easily be distinguished in table 5, e. g. "Polatucha" 832 is distinguished by particularly low reproduction: it aborted twice, dropped stillborn calves twice and one of its calves died soon after birth. Out of all the calves produced by this female it is only its first - "Pokusa" 975, which survived and the two calves born to the latter died soon after birth due to their low vitality. Several other females exhibit low fertility as the result of prolonged periods of sterility, and irregularity of calving connected with this, and also long intervals between calving. Such females include: "Puszka" 937 (Avg. calving interval - 20.0), "Polanka " 939 (22.5), "Purella" 979 (intervals between consecutive calvings respectively 16, 22 and 33 months), and "Punita " 935 (intervals of 25 and 36 months between the first three calvings). Cases of sudden loss of fertility after a period of normal high fertility are also encountered, as in the case of "Pociecha " 909, which 
began producing calves in its third year of life, produced 5 successive calves at regular intervals, then from that time onwards was permanently sterile (in the breeders' opinion due to growing very fat). Similarly, although without any visible cause, "Puleśna " 973 became sterile although it had promised to prove very fertile.

In the majority of cases the tendency which can be perceived by means of careful observations of rutting and reproduction processes in different females is confirmed during its later life. It is not difficult to discover both highly fertile females or poor reproducers on the basis of accurate breeding records. The case described here of the low fertility of »Polatucha" ard its daughter »Pokusa" unmistakably point to the hereditary basis of such tendencies. On the other hand the occurrence in some females of decidedly high fertility argues in favour of recognising this feature as a hereditary property. The practical conclusions arising from the foregoing may prove of considerable importance to breeding practice in reserves.

\section{Total increase from a female European bison}

Calculation of increase in young on the basis of the assumption that a female should calve every year from the time it attains sexual maturity is artificial. This kind of "potential fertility " can never be attained. Fertility over a female's lifetime can only be defined on the basis of calculated average duration of calving interval, and in order to assess total production of young it is essential to take into consideration in addition the mear length of a cow's period of fertility.

The duration of the fertile period can be defined on the basis of the mean length of life of a female bison, but the majority of authors determine this index inexactly, most often giving the extreme values. The values given in older literature are almost always too high (cf. $\mathrm{K}$ a r c ov, 1903; B a šlki r ov, 1940). The only reliable figures calculated from a group of animals more than 5 eyars old are those given by $\mathrm{Jaczewski}(l . c$. $), i$. e. 13 years. If it is assumed that the first three years of a female bison's life are infertile (first calving in the fourth year of life) a 10 year period of fertility remains. The calculation based on an index accepted in this way is too high already, as the oldest cows over 20 years old, the majority of which must have been sterile, also contribute to this figure. It may, however, be assumed (detailed calculations were not made), that under the present standarised conditions in reserve breeding the average lifespan of European bison may be longer than was the case at the start of the breeding operations in reserves and various zoological gardens. 
Taking the above data as the basis for calculating total increase it is found that an average female produces a mean number of $8.83 \quad(\approx \approx 9)$ calves in a reserve (10 years $=120$ months with average frequency of calving every 14.4 months). This is an approximate value as it includes stillborn calves and those which died soon after birth. We shall leave this error as we have no exact knowledge of the causes of death of all calves which would make it possible to distinguish between cases of deaths due to abnormal embryonic development and complications during birth and death due to accidents etc. (crushing by a falling tree, drowning, being trampled to death by adult animals, injury and killing of a calf by a male etc.). According to $\mathrm{Zablocki}$ (1957) mortality among calves during the first year of life was about $17 \%$ under reserve conditions.

VIII. EVALUATION OF FERTILITY AND INCREASE IN THE HERD

\section{Fertility}

The concept of fertility of a herd applies primarily to natural populations of animals. The total increase of young in European bison populations is affected by such factors as the fertility of females, the age structure of herds (participation in the herd of the fertile group of females), sex ratio and vitality of the young animals. Fertility of females in enclosed reserves may be used, within certain limits, for comparative investigations of the fertility of "breeding herds " especially in view of the fact that in the breeding of the European bison so far carried out efforts have been directed at making the fullest possible use of the reproductive capacity of these animals.

No visible differences were perceived in the reproduction of European bison in Polish reserves. In our opinion the very similar food conditions under which the animals are kept in reserves, the similarity of their management, care, phrophylaxis etc., should come within the limits of variation tolerated by the bison's organism. Differences between the Białowieża line bison bred in Polish reserves (i. e. all the bison at Białowieża and some at Pszczyna) and bison in which there is some degree of Caucasian blood (all the remaining), should not, practically speaking: play any important part in reproduction processes, even if only on account of the relatively negligible percentage of the Caucasian blood in this latter group of bison. In addition both forms exhibited under natural conditions greater similarity than is now observed in relation to the reserve "herds" in breeding centres geographically more distant and differing as to conditions (Cf. $\mathrm{Zablocki}$ 1949). The material we elaborated from the reserves can therefore be treated as homogeneous. 
Fertility of bison in reserves expressed by the percentage of fertile Iemales in the sexually mature group (from the 4 th year of life) is on the average $76 \%$, with variations from $63-91 \%$ in different years (Table 7). Changes in fertility over a period of years does not in this case represent the influence exerted by definite factors on the reproduction of the herd, if only on account of the fact of joint treatment of materials from different breeding centres and the low degree of representativeness of the series. Arrangement of the material in years is the only one in agreement with the natural periodicity of reproduction in the European bison and may thus constitute a scale for measuring the range of variations and extent of fluctuations in intensivity of reproduction under reserve conditions.

\section{Table 7.}

Per cent of calvings in breeding reserves and in freedom in relation to the number of cows capable of reproduction $(\mathrm{N})$.

\begin{tabular}{|c|c|c|c|c|c|c|c|c|c|c|c|c|c|c|}
\hline Year & 1954 & 1955 & 1956 & 1957 & 1958 & 1959 & 1960 & 1961 & 1962 & 1963 & 1964 & 1965 & 1966 & Total \\
\hline \multicolumn{15}{|c|}{ R P SBR VES } \\
\hline N & 14 & 21 & 23 & 25 & 31 & 33 & so & 28 & 28 & 27 & 29 & 26 & - & 315 \\
\hline \multirow{2}{*}{$\begin{array}{ll}\text { Calv- } & n \\
\text { 1.nzs } & x\end{array}$} & 12 & 16 & 21 & 17 & 24 & 30 & 19 & 21 & 20 & 18 & 23 & 21 & - & 242 \\
\hline & 85.7 & 76.2 & 91.3 & 68.0 & 77.4 & 90.9 & 63.3 & 75.0 & 71.4 & 66.7 & 79.3 & 91.3 & - & 76.82 \\
\hline \multicolumn{15}{|c|}{ IREEDOK } \\
\hline$n$ & - & - & - & - & 3 & 7 & 8 & 11 & 15 & 16 & 18 & 28 & 32 & 138 \\
\hline \multirow{2}{*}{$\begin{array}{l}\text { Calv- } \\
\text { Ings }\end{array}$} & - & - & - & - & 2 & 6 & 6 & 11 & 8 & 13 & 16 & 15 & 20 & 97 \\
\hline & - & - & - & - & \multicolumn{4}{|c|}{86} & 53 & 81 & 89 & 54 & 62 & 70.3 \\
\hline
\end{tabular}

The fluctuations in the number of calvings among free-living females (53 to $39 \%$ ) and also the mean value for the 9-year period of irre reproduction in the Białowieża Forest $(70.3 \%)$ are very similar to the corresponding values for animals living in enclosures (Table 7). Differences between average indices are not statistically significant. In order to explain this phenomenon it is necessary to take into consideration the specific character of a free-living herd due both to its current composition and to the conditions to which it is subject ( $\mathrm{Kras}$ in s k i. 1967). The cause of high fertility in cows in a free-living herd is undoubtedly intensive winter supplementary feeding, probably completely satisfying the quantitative and qualitative food requirements of bison during this period. Under natural conditions the animals were usually exposed to hunger during this period. Before the extinction of the natural herds oî European bison in BP Forest, at the turning point of the 19 th century. 
when the forest was unable to provide enough food for the numerous herds of big game, the fertility of the bison distinctly decreased and sterile periods of $2-3$ years occurred. During this time female bison in Białowieża enclosures most often calved every year (K a r c o v, 1903; $\mathrm{Kulagin,1919;} \mathrm{Wróblewski,} \mathrm{1927).} \mathrm{A} \mathrm{similar} \mathrm{fact} \mathrm{of} \mathrm{fertility}$ increase is given by $\mathrm{Zablocki}(1949)$ using as example the herds of crossbred European and American bison after the animals were moved in 1941 from the poor steppe areas of Askania Nova to the Caucasus, where they had better pastures and were given regular supplementary feeding. The absence of significant differences in fertility between a free-living and enclosed animals indicate that a free-living bison herds are not nowadays subject to the effect of limiting factors.

\section{Population increase}

A fuller description of the development dynamics of a free-living herd of Curopean bison is obtained by assessing the indices of real quantitative population increase. This makes it possible on the one hand to grasp the fluctuations in the population dynamics of bison under semi-natural conditions, and on the other permits of evaluating the degree to which such breeding is useful and effective in further restitution of the species. Quantitative indices of the renascent herd of European bison in BP Forest can be compared with analogical data obtained before complete extinction of the bison in this Forest ( $\mathrm{Karcov}, 1903$ ).

The list given by $\mathrm{Karcov}(l . c$.) contains the results of the annual estimations of European bison population made by the forest administration service from 1809 to 1902 . The author himself questions the relability of these official data, nevertheless as unique material they should be used for studies on the population dynamics of the European bison ( $\mathrm{Kulag}$ in, 1919; S evercov, 1940). The period from 1888 is to be taken as the most authoritative.

Analogical data on the development and dynamics of the present iree-living herd in the Białowieża Forest are not unfortunately free of error. Estimate of numbers is made extremely carefully in this case, but calculation is seriously complicated by the fact that further animals were released in successive years (either single animals or groups) with different proportions of sex and age. Each year has therefore been treated individually in calculating reproductive rate on the basis of full records.

Total increase of the free-living herd fluctuations within limits of $13-33 \%$ (increase in relation to the initial numbers of the herd in a given year). The mean value for a 9-year period (1958-1966) is 
maintained on a high level of $19.9 \%$, to which result both the considerable increase of young (average $22.4 \%$ ) and very low mortality contribute. According to W róblewski (1927) from 1889-1902 increase in young in the Białowieża bison population was on an average no more than $14 \%$, varying from $11-20 \%$ in different years. During this same period losses formed from $6-8 \%$ of the head, reducing total increase in the herd by nearly half. These losses were due to various causes (including shocting, both legal and poaching), but the official statistics state that the majority were due to deaths from disease or old age (K a rcov, 1903). In Wróblewski's opinion, however, the chief cause of low population increase was the high mortality among the young, forming $49.3 \%$ of the whole annual increase. In the present free-living herd, on the other hand, mortality among calves up to 1 year old does not exceed $2.29 \%$ of the increase in young ( $\mathrm{Kr}$ a sins $\mathrm{ski}$, 1967). In relation to herd numbers for the whole period during which the animals have lived in freedom this is only $0.5 \%$. The high rate of population increase in free-living herds is due to several causes. The exceptionally small losses in the group of adult animals (only 9 animals died during the whole period of free-living breeding) may be explained by the current age structure of the herd. At the present time young animals form $42 \%$ of the herd ( $\mathrm{Krasinski}$, 1967) which, differs greatly from the model of natural age structure in a population of animals with similar reproductive potential and longevity. This situation, although abnormal from the point of view of natural population processes, is extremely favourable from the aspect of herd increase in the near future.

The extremely low mortality rate among young animals deserves special emphasis. It is at present difficult to state to what degree this is connected with the present age structure of the herd. In view of the frequent cases observed of calves dying as the result of injury by adults and old males it may be assumed that this factor plays a certain part. Wróblewski (1927) considered that the chief cause of high mortality rate among young animals was due to unfavourable living conditions. If these conditions consisted merely in the food factor, then it is true that a very great improvement has taken place in the Białowieża Forest in this respect (rich undergrowth, reduced competition from red deer), while the bison now receive better care in the winter.

There is no doubt that the phenomenon of particularly intensive herd increase is to some degree transistory and may be expected to drop after reaching optimum numbers and herd struccure. If this moment can be grasped, it will undoubtedly be of great practical importance to free- 
living breeding of bison, since the parameters of habitat and intra-population factors are known.

\section{SEX RATIO}

A large number of observations and numerical data have been accumulated for a long time in literature on the subject of sex ratio in the European bison, despite which this question has not as yet been closed. Mention is encountered in the oldest sources of unequal sex ratio in wild bison populations. The majority of the authors speak of the clear predominance of males, both in the case of Białowieza and Caucasian bison (B r incken, 1826; K a r cov, 1903; B a škirov, 1939). It is possible that this view has been adhered to for so long as a result of the opinion established by Usov and Büchner (cited after Ba skirov, 1939) that the fact of a greater number of males than females being born proves a tendency to natural extinction of the European bison.

In more recent studies $\mathrm{Zablocki}$ (1957), basing his findings on a large amount of material from enclosure breeding, demonstrated that cow bison predominate. In addition he made a detailed analysis of variations in the ratio of males to females in different years, both in populations stocking reserves and in the annual increase in young, and found considerable variations. During the same period $\mathrm{Jaczc}$ 'ski (1958) obtained on the basis of records in pedigree books of the sex of calves born, ratios similar to the $1: 1$ ratio in respect of a very considerable amount of material.

These apparently contradictory data on the sex ratio in the Eurcpean bison can be logically explained, if the possibility is accepted that sex ratio in a population may differ in different age groups of the animals. Another reservation of a methodical nature is required when evaluating fluctuations in sex ratio in different years. This index belongs to the phenomena which are revealed statistically when the number of observations is sufficiently large. This imposes limits on ali conclusions and speculations based on material which is insufficiently representative.

1. Sex ratio at birth - this can be treated as being closest to the primary sex ratio established at the moment of fertilisation. Up to the moment of birth it can be modified only by selective action of intra-uterine mortality. In the material examined, out of 249 births of live and dead calves in reserves during the period from 1954-1965 the ratio of males to females was $138: 111$ ( $1: 0.30)$, which does not differ statistically significantly from the ratio $1: 1$ (test $\chi^{2}$ ). A balanced sex ratic also occurs in $J$ a c zewski's material (l. c.) and also in the comparison of sexes of calves born in different breeding reserves in the world, as given by $\mathrm{Zablocki}(1957)$. The ratio of $233: 233$ is obtained from the data given in table 8 (p. 35) of the study by the author referred to.

The sex ratio of calves bcrn in the free-living bison population in the Białowieża Primaeval Forest for the period 1958-1966 is 52 : 46 (1:0.89), which does not differ significantly from the theoretical ratio of $1: 1$ (test $\chi^{2}$ ). 
2. Sex ratio in the herd - a significant predominance of remales is usually revealed. This phenomenon was observed by $\mathrm{Z}$ ab locki (1957) in the head of bison in BPF given by W r o blew ski (1927) in 1909 (256:329) and also in his own statistics covering all the European bison living in the world during the period 1921-1951. We obtain the following proportions from his data: for Białowieża bison $557: 734$, for bisons of the Caucasus and Białowieża lines jointly $1273: 1389$. All the proportions given above differ significantly from the $1: 1$ ratio in favour of females.

The facts presented prove that sex ratio in a bison population is subject to variations, the causes of which should be sought for in the different mortality of the two sexes in postnatal life. A study was made of the sex of all calves which died in reserves during the first year of life. The ratio of 22:5 obtained reveals the decided predominance of males and excludes the possibility that the result is fortuitous. $\mathrm{Z}$ ablocki (1939) also found marked predominance of mortality among males in herds of crossbred European and American bison in Askania Nova during the period from 1907-1938, where out of a total number of 78 stillborn calves $21 \%$ were males and $10.3 \%$ females. In the Białowieża reserve alone during the period from 1954-1965 abortions and mortality among calves caused $18 \%$ losses of the total increase of young. W r o blewski $(l$. c.) mentions losses of as much as half the increase in young in a year. If the proportions of this mortality among males and females are borne in mind the change in sex ratio on the group of adult bison becomes easy to understand. The relations observed in the reserves do not appear to from a special case. The lists of losses in the Białowieża bison population given by $\mathrm{Wr}$ óble w ski $(l$. c.) from 1889-1907 show the proportions for adult animals are 427 males and 308 females, significantly differing from the ratio $1: 1$. Although varied causes of losses in head of bison during this period are involved, the majority of the animals died from causes not directly due to humen intervention (diseases, old age, accidents, results of fights between animals, depredations of wolves and bears etc.).

The examples given show that the males in a bison population have less vital force than the females. They are subject not only to higher mortality rate at birth and during the juvenile period, but also during their later free life in the herd. Under natural conditions it is possible that behavioural factors also influence the higher mortality rate in adult males (fighting between males or leading a lone life away from the herd), but in relation to males in general it is primarily factors of a physiological nature, connected with lower resistance to unfavourable 
conditions, infections and diseases, which exert the greatest influence, resulting in the life span of males being statistically shorter than that of females ( $\mathrm{Z} \mathrm{a} \mathrm{b} \mathrm{J} \mathrm{ocki,} \mathrm{1957;} \mathrm{J} \mathrm{a} \mathrm{c} \mathrm{zew} \mathrm{ski,} \mathrm{1958).}$

It would appear that the change in sex ratio in favour of females in successive age groups of bison forms a rule of population development under natural conditions. This does not mean, however, that operations aimed at artificial formation of the sex ratio in favour of females in enclosed populations controlled by man serve any useful purpose. Consideration should also be given as to whether the use of a very limited number of male reproducers in breeding practice in reserves serves a useful purpose. The sex ratio in enclosed breeding proposed by $\mathrm{Z} \mathrm{a} \mathrm{blocki}$ (1957), of 1 male to 10 females, would not appear desirable during the phase of restituting the European bison, if only for genetic reasons.

\section{SEXUAL BEHAVIOUR}

The behaviour of European bison has not so far formed the subject of a separate study. Many ethological observations referring both to the behaviour of a herd and of individual animals are to be found in monographic elaborations of the species (K a r cov, 1903; Wróblewski, 1927). J a c ze w ski (1958) has devoted a considerable amount of space to the behaviour of bison in connection with reproduction.

During the rutting period males exhibit special excitement. While placid for the greater part of the year, they become aggressive during this period, driving other males away, and they may even attack humans. It is during this time that cases occur of calves being injured or even killed when they attempt to suck their mothers. Some bulls drive the calves away fairiy gently "Podbipięta", while others attack them violently, e. g. "Karpacz". This latter bull has already killed several calves in reserve and injured 3 . A case of a calf being killed by a bull was also recorded in 1961 among free-living herd. The bulls also work off their aggressiveness and excitement in fights with other males. In the reserves two bulls living in adjacent enclosures often break through the strong wooden fencing and start fights which usually last a long time, but only rarely cause the antagonists' death. In one case a fight of this kind ended in the bull "Pokaz " being fatally injured. A typical manifestation of the aggressive behaviour of males towards other bulls is breaking young trees, pawing the ground with their fore feet and rolling on the ground.

The only manifestations of oestrus in females under normal circumstances is their allowing the male to cover them, and not very marked symptoms of excitement. In the experimental reserve of the Mammals 
Research Institute two female bison kept without a male during oestrus kept attempting to jump up on each other. Similar manifestations were encountered only twice in female bison in the breeding reserves at Bialowieża and Niepolomice.

Copulation is preceded by a period when the bull "attends" the cow. For 1-2 days the male never leaves the cow, licks the latter's vulva, makes movements simulating the jump on the female's hindquarters, and while doing so utters the sound termed "snoring:. It frequently smells the cow's external genitalia, stretching and characteristically wrinkling its nose. The manifestations of "attendance" form the best evidence that oestrus is occurring in a female bison. Most often on the third day after the first manifestations of attendance have been observed, the female bison allows the bull to cover it, which it usually does once or twice that day, then ceases to take any interest in the cow. Jaczewski (1958) observed 4 such coverings in one day. After copulation the female exhibits for several hours the so-called "manifestations of copulation" ( $\mathrm{Ja} \mathrm{c} \mathrm{z} \mathrm{ew} \mathrm{ski,} \mathrm{1958),} \mathrm{expressed} \mathrm{by} \mathrm{humping} \mathrm{its}$ whole body and holding its tail out stiffly.

In free-living populations of European bison the start of the rutting period is signalled by the adult bulls joining the herds, which are composed chiefly of female and young animals ( $\mathrm{Kr}$ a sins ki, 1967). In the Białowieża Forest this takes place towards the end of July. The strongest males then drive off the young bulls, which until then had lived with the cows, and during the rutting period keep at some distance from the herd and do not take part in reproduction. No such fights between bulls as were frequently described by earlier authors ( $\mathrm{K}$ a rcov, 1903; K u lagi n, 1919) have so far been observed in free-living bison, but the bulls have often been observed to break young sprucę, overturn stumps etc. which is behaviour often exhibited by excited males in enclosures. There are no exact data available on the time at which the males leave the herds. In reserves in which the bulls often spend the whole year with the cows in one enclosure it was noticed that during calving time the bull separates from the cows and lives on its own.

Calving observed in reserves is preceded by characteristic behaviour of the female, which ceases its visits to the feeding place, or only appears for a short time, a few days before birth takes place. Sometimes the whole herd living in the enclosure is absent at feeding time. According to $\mathrm{Karcov}$ (1903) in natural populations also the female bison leaves the herd from 5-6 days before calving and returs with its calf after the birth. The female usually calves during the night or early morning, and itself eats the placenta (W r ob lew ski, 1927). The calf 
gets to its feet soon after being born and a few hours later is able to run after its mother. The female never leaves the calf for several weeks, and even in cases in which the calf died the mother stood over it for up to 3 days and allowed no-one to approach. The female does not come to the feeding place for the first few days after calving, although in a few cases this took place on the day after calving. If there is little natural food in the enclosure the female leaves its calf hidden in the forest in the interior of the enclosure and itself approaches the feeding place only in order to seize a little food, and then at once returns to its calf.

There are no exact data available on the duration of lactation and suckling in the female bison. The calf continues to suck its mother for a long time, even when it has begun feeding independently. W r ó b l e wski's observations (1927) are confirmed, both in reserves and in free-. living populations, that wellgrown animals born the previous year readily suck the mother side by side with young calves.

\section{DISCUSSION}

At the present time, when it is as yet too early to cross the European bison off the list of species threatened with extinction, one of the chief tasks of its protection is the rational breeding of this animal, enabling maximum advantage to be taken of its biological capacities with the minimum disturbance on the part of man. This condition is particularly difficult to meet with regard to a process of such fundamental importance to building up the head of bison as is reproduction. Many phenomena may have an influence on reproduction which is not always easy to identify, beginning with abiotic habitat factors, then food conditions, and ending with influences connected with behaviour properties. The experience gained over a long period of breeding has supplied knowledge on many basic factors conditioning intensivity of reproduction in the European bison and quantitative increase in the head of these animals. A particularly valuable source supplementing this knowledge is formed by observations under natural conditions. The state of knowledge we now possess on reproduction among bison in enclosed breeding reserves, combined with the information contained in older studies on natural populations and the first results of keeping free-living herds in the Białowieża Forest, enable a critical review to be made of the whole group of natural and artificial factors which affect the reproduction and population increase of the European bison.

According to $\mathrm{Z} \mathrm{a} \mathrm{b} \mathrm{locki} \mathrm{(1949)} \mathrm{under} \mathrm{good} \mathrm{conditions} \mathrm{a} \mathrm{bison} \mathrm{popul-}$ ation is characterised by: (1) a distinctly defined and correctly timed calving season, (2) considerable regularity of annual calving in females, 
(3) low mortality rate among young animals. There are many proofs available that deviations of any one of these indices signals the existence of phenomena unfavourable to the population, while their removal brings about visible improvement.

1. Habitat factors. Climatic factors, according to $\mathrm{Z}$ ab locki (1949), may be responsible for the differences in time of occurence of cestrus in bison between the Polish reserves and the Askania Nova reserve and Swedish Avesta. Local climatic conditions, in addition to specific breeding conditions, most certainly form the cause of females calving at various times over the whole year in different zoological gardens over the world. 'The climatic factor does not however play any perceptible part in a region covering the original natural range of the European bison.

Where European bison are kept in enclosures, the size of the enclosure is important. Enclosures which are too small, such as those in which bison were first kept at Pszczyna and Białowieża, have an unfavourable effect on the course of reproduction. These symptoms disappeared after increasing the area of these reserves $(\mathrm{Z} \mathrm{a} \mathrm{b} \mathrm{lock} \mathrm{i,} \mathrm{1949).} \mathrm{It} \mathrm{would} \mathrm{seem}$ that the food factor played an important part in this case. Crowding. however, tends to increase the number of cases of young animals being killed by old ones, such as occurred, e. g. in the Swedish reserve Avesta ( $\mathrm{Z}$ a b l o c k i, 1957).

The direct influence of the habitat may be expressed in increased mortality among young and adult animals as the result of accidents. Wróblewski (1927) describes numerous cases of the death or serious injury of European bison in the Białowieża Forest due to falling trees, to becoming entangled in uprooted trees, drowning in the mud of river valleys etc.

2. Food. The food factor manifests its action very early in bison breeding. The reason for this is the fact that the natural habitat of the bison has undergone very great changes as the result of human management. Under natural conditions the forest provided the bison with sufficient food supplies over the full yearly cycle. Young shoots, branches and bark form on an average half the food eaten by bison ( $\mathrm{Z} \mathrm{a} \mathrm{b} \mathrm{locki,1957;} \mathrm{K} \mathrm{or} \mathrm{očk} \mathrm{in} \mathrm{a,} \mathrm{1966).} \mathrm{There} \mathrm{can} \mathrm{be} \mathrm{no} \mathrm{doubt} \mathrm{that}$ during snowy wirters such as often occur at Białowieża, this component must have almost completely met the food requirements of the bison, while in summer it was supplemented by succulent fodder.

During the time when the first scientific elaborations appeared the bison in the Białowieża Forest encountered conditions which had already been greatly transformed by man. In the second half of the 19th century. as the result of intensive artificial breeding in the Forest of red deer, 
fallow deer and elk, the living conditions of bison markedly deteriorated. The particularly intensive reproduction of red deer led to almost complete exhaustion of the bison's natural food supply at the turning point of the 19th century. According to $\mathrm{W} \mathrm{rob} \mathrm{lew} \mathrm{ski}(l . c$.$) this had$ a distinct effect on the development, reproduction and condition of the bison, manifested by, inter alia: late sexual maturation, low calving rate and increased mortality among the young animals, which radically reduced the development rate of the population. Information on the first calving taking place when the females were $5-6$ years old ( $\mathrm{Br}$ incke n, 1826; K u lag i n, 1919) with subsequent calving occurring only every 2-3 years come from this period. Female bison kept at that time in special enclosures with the aim of supplementing the natural population, and fed with hay and oats, calved almost every year ( $\mathrm{St}$ e c how, 1929).

The conditions of contemporary enclosure breeding of bison, ensuring high reproductive rate, are based on supplementary feeding. The animals are given highcalorie fodder throughout the whole year (oats, barley) and hay and root crops in winter. During the growing season natural plant food growing in the forest area is the basic component. In extensive enclosures the bison feed in the interior for the greater part of the day in summer, and often do not appear at the feeding places for days on end. The part played by artificial feeding does not become important until the critical period, and then forms a significant factor differentiating the living conditions of the enclosed herd from those of natural populations.

A free-living bison population is able to make use of the natural food supply in the Forest throughout the whole year, but in fact during the time that there is a deep snow cover the animals gather round the feeding places and do not leave them until the summer growing season (Krasinski, 1967). Such conditions have proved favourable to the bison population, as is expressed in the high birth rate and population increase which does not differ from the parameters characteristic of the herds enclosures. It must be emphasised that the present food supply in the Forest meets the bison's requirements better than during the period of maximum density of ruminants at the beginning of the 20th century (Borowski, Krasiński \& Miłkowski. 1967). The fundamental difference, however, consists in the elimination of the effect of hunger, which was most certainly a normal phenomenon in the early spring. According to $\mathrm{J} \mathrm{a} \mathrm{c} \mathrm{z} \mathrm{ew} \mathrm{ski}(l . c$.) the "hunger period" presumably lasted about two months and formed an important physiological moment in the annual periodicity of the bison's life. There is no doubt 
that the deterrioration in living conditions caused considerable mortality and weakened the animals in some years. This regulating effect of natural selection has now been completely eliminated by supplementary feeding, but the animals' good conditions over the whole year is to a great extent the result of their using the natural food supply. The ability of the bison to move about the Forest, combined with the considerable biotopic differences in their environment, enables them to make a free choice of feeding place, depending on their food preferences.

It must be stated that food forms the basic limiting factor of a bison population. Their ability to feed in the forest determines the condition of animals bred in enclosures and is one of the reasons why the breeding of free-living bison in the Białowieża Forest has proved so successful.

3. Population factors. The group of factors connected with the bison population structure plays an important part in regulating the processes of herd organisation and increase under natural conditions. The experience obtained in breeding free-living bison over the recent period points to the necessity for taking these factors into consideration.

The present bison population in the BP Forest is to a very great extent an artificial population. Its age and sex composition is the result of gradually setting animals free from the breeding reserves, the sex and age proportions being in principle entirely accidental. During their free reproduction, conditions favouring the formation of the natural organisation of herds were artificially disturbed by releasing further animals. Despite these disadvantages, signicifant from the aspect of population studies, the free-living herd in its present form provides interesting material for analysis of reproduction and population increase.

Differences in reproduction between free-living bison and those kept in reserves consist chiefly in the former's selfregulation of the seasonal rhythm of sexual activity. In our opinion the main cause of the return to the natural rutting time is the effect of intrapopulation factors. Herd organisation similar to the natural one, grouping the cows together with young animals and separation of active males, with the bulls joining the females at the beginning of the rutting season, most certainly constitute a factor evening up intensivity of oestrus in the whole population. The shortening of the rutting period observed is due to the greater effectiveness of copulations. The influence of population factors on this phenomenon may be analogical to that observed in some domesticated species, i. e. increased percentage of fertilisations when coverings take place in the herd in comparison with controlled copulation such as in the case of horses (Bielański, 1962).

The high calving rate among free-living animals proves that when limiting factors are absent the reproductive potential of the European 
bison under semi-natural conditions is the same as in the enclosures. The exceptionally high level of population increase among free-living animals is however undoubtedly a transitory phenomenon due to the currently existing age structure. During the last few years annual increases fluctuated in free-living herd within limits of $18-33 \%$, the average being $20 \%$. Comparison with the rate of population increase among bison in the Białowieża Forest at the end of the 19th century (after S e verc ov, 1941 - from 2.7 to $4.4 \%$ ) or during the period of trial and error with breeding bison in reserves $(6.4 \%$ after $\mathrm{Z} \mathrm{ablocki}, 1957)$ shows how exceptional a phenomenon this is.

When the free development of the herd proceeds withcut intervention it may be expected that the natural age structure of population will be attained in the future. This will make it possible for the population development rate to become stabilised and the progressive phase of population development will be at an end. It is therefore obvious that acceptance of the present indices as a basis for forecasting free-living herd increase is unjustified. It would appear to be one of the most important problems for the future restitution of the European bison by methods of keeping a free-living population to establish the indices of population increase depending on its structure and to define population potential under natural conditions.

4. Genetic factors. The detailed analysis we made of the fertility of female bison in breeding reserves made it possible to establish, that there are individuals distinguished by reduced fertility. By analogy with the relations observed in domestic animals it would seem that at least some of similar cases are due to genetic factors. This is the more probable in relation to the European bison in which the present head was obtained from the initial herd numbering, according to the estimates made by the International Society for the Protection of the European bison, about 40 animals capable of reproduction. Further breeding carried out independently in several centres took place under conditions of intensive inbreeding. Mating of closely related animals takes place at the presert time also in breeding reserves. In such circumstances it is only lethal characters which are eliminated by the death of the young. Others, such as reduced fertility, can only be gradually eliminated in natural populations subject to the factors of natural selection. As increased fertility of female bison is an important factor facilitating. quicker successes in the restitution of the European bison, the question rises as to whether certain operations of selection for fertility should not be carried out in breeding practice. With the present head of bison such operations should be limited to eliminating from reproduction cows with tendencies to irregular calving, abortions or dropping calves with 
low vitality. In our opinion there is no need to fear that this operation would produce undesirable side-effects to the species, since it is a question here of the general property of biological vitality, and not of selection aimed at any one defined character. The only places in which breeding work of this kind could be carried out with the aim of improving natality in the herd are enclosed breeding centres. Estimates should be based on detailed documentation including above all the whole of the lemale bison, arranged from the aspect of purposely chosen criteria for estimating fertility. The opportunity of selecting by this means individuals most valuable from the standpoint of population increase should be used, particularly in further attempts at breeding free-living bison.

\section{CONCLUSIONS}

At the present stage of restitution of the European bison the chief aim of breeding is to achieve rapid increase in the head of this species in the world. From this aspect research on reproduction of European bison under the conditions formed by the present metheds of enclosed and free-living breeding supplied material permitting of reaching the following conclusions:

1. Enclosed breeding of bison, based on methods elaborated over years of experimentation, now ensures that the reproductive potential of the species is utilized to a very great extent. The first results of free-living breeding in the Białowieża Forest prove that the fertility of the herd does not change in a natural habitat when the animals are given intensive supplementary feeding in the winter, but that a tendency, favourable from the standpoint of this species' biology, appears to recreation of the natural seasonal rhythm of reproduction. This makes the free-living breeding of bison the method of choice, as being better justified from the aspect of the bison's biology.

2. The results obtained so far from breeding bison in enclosures and in free-living herds, and observations of natural populations, justify the statement that the basic factor limiting bison's fertility is food.

3. An important factor regulating the reproduction dynamics of free-living bison herds is the natural course of population processes expressed by the spontaneous formation of age, sex and social structure of herds. This indicates that human interference in the free development of free-living bison herds should be limited as far as possible.

4. It would appear desirable with the present head of bison to introduce the principles of elimination of individuals with lower vitality and fertility in enclosed breeding centres, in order to increase the reproductive potential of the species and improve breeding material. 
5. Free-living populations of European bison should always be maintained, by releasing only perfect young animals in sex-ratio 1:1 and ensuring that the natural development of these populations continues is an important factor of further research on the biology and ecology of such populations.

\section{REFERENCES}

1. Asdel1 S. A., 1946: Patterns of mammalian reproduction. Comstock Publish Co.: 1-437. Ithaca.

2. B a škir ov I., 1939: Kavkazkij zubr. In „Kavkazkij zubr”. Glavnoje upravlenie po zapovednikam, zooparkam i zoosadam: 3-72. Moskva.

3. Bi elánski W., 1962: Rozród zwierząt gospodarskich. Państw. Wyd. Roln. Leśne: 1-546. Warszawa.

4. Borowski S., Krasiński Z. \& Miłkowski L., 1967: Food and role of the European bison in forest ecosystems. Acta theriol., 12, 25: 367-376.

5. Brincken J., 1826: Mémoire descriptif sur la forêt impériale de Białowieża en Lithuanie. Imprimeur-Librarie de L'université Royale: 1-127. Varsovie.

6. Gill J., 1967: The physiological properties of the European bison. Acta theriol., 12, 23: $349-360$.

7. Heptrier V. G., Nasimovič A. A. \& Bannikov A. G., 1961: Mlekopitajušče Sovetskogo Sojuza. I. Parnokopytnye i neparnokopytnye. Gos. Izd. ,Vysšaja škola": 1-776: Moskva.

8. Jaczewski Z., 1958: Reproduction of the European bison, Bison, bonasus (L.), in reserves. Acta theriol., 1, 9: 333-376.

9. Kalug in C. G., 1958: Zubry v estestvennyh uslovjah Kavkazkogo zapovednika. Tr. Kavkazsk. gos. zap., 4: Majkop.

10. K a r ov G., 1903: Belovežskaja Pušča. Artist. Zaved. A. F. Marksa: 1-414. Petersburg.

11. K or očkina L. N., 1966: K voprosu o značenii drevesnoj rastitelnosti v pitanii zubrov Belovežskoj Pušči. Vesci AN BSRR, 1: 106-111.

12. Krasińska $M_{\text {, }}$ 1963: Weitere Untersuchungen über Kreuzungen des Wisents, Bison bonasus ( $\mathrm{L}$ in na e us, 1758) mit dem Hausrind, Bos taurus dom., Linn a e us, 1758. Acta theriol., 7, 14: 301-310.

13. Krasiński Z., 1963: O żubrach na wolności w Puszczy Bialowieskiej. Chr. Przyr. Ojcz., 19, 5: 3-7. Kraków.

14. Krasiński Z., 1967: Free living European bisons. Acta theriol., 12, 29: 391405.

15. K $\mathrm{rysiak \textrm {K }}$, 1967: The history of the European bison in the Bialowieża forest and the results of its protection. Acta theriol., 12, 19: 323-331.

16. Kulagin N. M., 1919: Zubry Belovežskoj Pušči. Izd Mosk. Naučn. Inst.: 1166. Moskva.

17. Mohr E., 1952: Der Wisent. Die neue Brehm-Bücherei. 74: 3-75. Leipzig.

18. Nalbandov A. V., 1958: Reproductive physiology. Comparative reproductive physiology of domestic animals, laboratory animals, and man. W. H. Freeman and Co.: 1-271. San Francisco.

19. Pedigree book of the European bison 1955-1961. International Society for the Protection of the European bison. Warszawa.

20. Pfizenmayer E. W., 1929: Biologische und morphologische Notizen über den Kaukasuswisent. Abh. math.-naturwiss. Abt. Bayer. Akad. Wiss. 11, Beitr. 
zu Nat.- u. Kulturgeschichte Lithauens u. angrenz. Gebiete: 497-504. München.

21. Severcov S. A.: 1940: Vidovye konstanty razmnoženija belovežskogo zubra i dinamika naselenija etogo vida. Tr. Inst. evoljuc. morfol. im. A. N. Severcova, 3, 1: 3-32.

22. Severcov S. A., 1941: Dinamika neselenija i prisposobitelnaja evoljucija životnyh. Izd. AN SSSR: 1-316. Moskva-Leningrad.

23. Ste chow E., 1929: Uber die einstige Hege des Wisents im Urwalde von Bialowies. Abh. math.-naturwiss. Abt. Bayer. Akad. Wiss. Suppl., 12. Beitr. zur Nat.- u. Kulturgeschichte Lithauens u. angrenzender Gebiete: 505-507. München.

24. Studiencow A. P., 1956: Położnictwo i ginekologia weterynaryjna. Pañstw. Wyd. Roln. Leśne, 1-703. Warszawa.

25. Wr óblewski K, 1927: Żubr Puszczy Białowieskiej. Wyd. pol., 1-234+XVI. Poznań.

26. Z a blockaja L. V., 1957: Pitanie i estestvennye korma zubrov. Tr. Prioksko-Terrasn. gos. Zap., 1: 66-143. Moskva.

27. Zablocki M. A., 1939: Tridcat' pjat' let razvedenija zubrov i ih gibridov $\mathrm{v}$ zooparke Askanija-Nova. In „Kavkazkij zubr”. Glavnoje upravlenije po zapovednikam zooparkam i zoosadam: 73-137. Moskva.

28. Z ablocki M. A., 1949: Neobhodimost' izučenija osobennostej zubra i ego vosstanovlenie v SSSR. Nauč.-Metod. Zapiski, 13: 128-146. Moskva.

29. Z a blocki M. A., 1957: Nekotorye biologičeskie osobennosti zubra i ih izmenenie $\mathrm{v}$ uslovijah zagonnogo soderžanija. Tr. Prioksko-Terrasn. gos. Zap., 1: 5-65. Moskva.

Received, May 30, 1967.

Białowieża National Park

and

Polish Academy of Sciences,

Białowieża, Poland. Mammals Research Institute, Białowieża, Poland.

\section{Zbigniew KRASIŃSKI i Jan RACZYṄSKI}

\section{BIOLOGIA ROZRODU ŻUBRA W REZERWATACH I NA WOLNOSCI}

\section{Streszczenie}

Autorzy wykorzystali do badań urzędową dokumentację krajowych Ośrodków Hodowli Żubra w Białowieży, Niepolomicach, Pszczynie i w Borkach za okres 1954-1965, biorąc pod uwagę terminy pokryć, wycieleń i płeć potomstwa oraz obserwacje dotyczące innych przejawów aktywności płciowej krów i byków, zawarte $\mathrm{w}$ notatkach hodowlanych. Rozród zubrów na swobodzie badano analizując w kolejnych latach sezonowość wycieleń, przyrosty i rozwój wolno bytującego na terenie Puszczy Białowieskiej stada w okresie 1958-1966.

Stwierdzono, że sezon godowy u żubrów w rezerwatach rozciąga się od lipca do marca, zaś na miesiące kwiecień, maj i czerwiec przypada u samic okres anoestrus. Większość pokryć zachodzi w okresie: sierpień - październik (Tabela 1). Sezon wycielen rozciąga się odpowiednio od kwietnia do grudnia $w$ rezerwatach $\mathrm{i}$ od maja do września (sporadycznie tylko obejmuje miesiące listopad i grudzień) na swobodzie (Tab. 2). Większość wycieleń ma miejsce w maju, czerwcu i lipcu, zarówno w rezerwatach $(70 \%$ ), jak i na wolności $(80 \%)$ - (Ryc. 1). Czas trwania ciąży u żubra ustalono na 254-272 dni, srednio 264,3 dnia (Ryc. 3). 
Żubrzyce dojrzewają płciowo najczęściej w trzecim roku życia. Pierwsze wycielenie dokonuje się zwykle w czwartym roku życia $\left(54^{\%} / 0\right)$, średnio dla badanej populacji rezerwatowej w wieku 33 miesięcy (Tab. 3). W piątym kalendarzowym roku życia wszystkie samice mogą być już traktowane jako zdolne do rozrodu (Tab. 4). Potencjał rozrodezy żubrzyc w chwili przystąpienia do rozrodu nie ulega większym zmianom aż do zakończenia okresu płodności (Ryc. 4). Objawy rui u żubrzyc widoczne są zwykle w ciągu 1-3 dni. Długość cyklu płciowego waha siñ najczęściej w zakresie od 18 do 22 dni, średnio trwa 20,6 dnia (Ryc. 2). Wznowienie cyklu płciowego po wycieleniu zackodzi u więlsszości żubrzyc w okresie do trzech miesiçcy: najwcześniejsze skliteczne pokrycie zarejestrciwano w 13 dni po wycieleniu. Okres międzywycieleniowy wynosi u najbardziej płodnych krów 10-13 miesięcy, przeciętnie 14,4 miesiąca (Tab. 5).

Przeprowadzonc szczegółową analizę płodności poszczegúlnych żubrzyc z rezerwatów hodowlanych, uwzględniając czas osiągnięcia dojrzałości płciowej, frekwencję wycieleń w kolejnych latach oraz sezonową rcgularnośc por’dów. Pozwoliło to na wytypowanie grupy najbardziej płodnych krów (wczesna dojrzałość, średni okres międzywycieleniowy 10-13 miesięcy, zdrowe potomstwo) oraz wyróżnienie żubrzyc o obniżonej płodności (częste okresy jałowienia, poronienia, rodzenie martwych lub mało żywotnych cieląt) - (Tab. 5). W korzystinych warunkach rezerwatowych rodzi corocznie 63-91\% żubrzyc zdolnych do rozrodu. Przejściowa jałowcśś ma związek $\mathrm{z}$ terminem ostatniego wycielenia, padnięciem cielęcia $\mathrm{w}$ okresie karmienia oraz wynika z zespołu innych, nieznanych przyczyn. Istnieje możliwość, że u nisko płodnych żubrzyc zjawisko to ma charakter dziedziczny. Przyjmując wynikający z długości życia 10-cio letni okres płodności żubrzycy, jedna samica w rezerwacie daje w ciągu życia przeciętnie 9 cieląt.

Płodność stada wolnego, wyrażona procentem $\dot{z} u b r z y c$ wycielonych $w$ stosunku do ogółu zdolnych do rozrodu wynosi średnio $70,3 \%$ i nic różni się istotnie od płodności żubrzyc w rezerwatach zamkniętych $76,8 \%$ (Tab. 7). Wysokie przyrosty ilościowe wolnego stada (13-33\% rocznie, średnio $19,9^{\prime \prime} \%$ ) są wynikiem dużego przyrostu młodych (średnio $22,4 \%$ rocznie) oraz minimalnej śmiertelności cieląt $(2,3 \%)$. Intensywny rozwój stada na swobrdzie tłumaczy się również istniejącą aktualnie - sztuczną strukturą wiekową i píciową stada.

Stosunek płci przy urodzeniu nie odbiega od proporcji 1:1 $(\mathrm{n}=249)$.

W celu uchwycenia czynników, od których zależy intensywność i prawidłowy przebieg rozrodu żubrów przeprowadzono porównawczą analizę rozrodu stad żubrzych w zależności od metody (zamknięta, półwolna) i ogólnych warunków hodowli. Stwierdzono ograniczający wpływ czynnika pokarmowego, zarówno od strony zapotrzebowania ilościowego, jak i składu jakościowego (udział składników naturalnych) oraz regulujące działanie stosunków wewnątrzpopulacyjnych, związanych $\mathrm{z}$ istnieniem $\mathrm{w}$ wolnych populacjach naturalnej struktury socjalnej stad.

$\mathrm{Z}$ punktu widzenia postępów restytucji żubra autorzy oceniają pozytywnie metodę wolnej hodowli, która w korzystnym środowisku i przy aktywnej opiece człowieka zapewnia wysoką płodność stada i rekonstrukcję naturalnego rytmu sezonowego. Ze względu na doniosłe znaczenie poznawcze prowadzenie hodowli tą metodą winno odpowiadać zasadom eksperymentu naukowego przy zachowaniu warunków dla swobodnego wzrostu populacji. Ośrodki zamkniętej hodowli żubrów są terenem, gdzie można prowadzić prace w kierunku zwiększenia potencjału rozrodczego stada hodowlanego i eliminowania szkodliwych skutków wieloletniego chowu wsobnego poprzez szczególową kontrolę i stosowanie zasad selekcji w stosunku do osobników przenoszących cechy obniżonej żywotności i płodności. 